\title{
Soft sediment deformation in the shallow submarine slope off Nice (France) as a result of a variably charged Pliocene aquifer and mass wasting processes
}

\author{
Kopf Achim ${ }^{1,}{ }^{*}$, Stegmann Sylvia ${ }^{1}$, Garziglia Sebastien ${ }^{2}$, Sultan Nabil ${ }^{2}$, Henry Pierre ${ }^{3}$, \\ Dennielou Bernard ${ }^{2}$, Haas Simon ${ }^{1}$, Weber Kai-Christian ${ }^{1}$
}

${ }^{1}$ Marine Geotechnics, MARUM - Centre for Marine Environmental Sciences and Faculty of Geosciences, University of Bremen, Bremen, Germany

${ }^{2}$ Ifremer - French Research Institute for Exploration of the Sea, Centre, de Brest, Plouzane, France

${ }^{3}$ CEREGE - Université Aix-Marseille III, Collège de France, Aix en Provence, France

* Corresponding author : Achim Kopf, email address : akopf@marum.de

\begin{abstract}
:
Along the Ligurian slope near Nice, southeastern France, a combination of natural and man-made factors govern slope stability, and contributed to a devastating tsunamigenic landslide near Nice airport in 1979. Based on a total of 72 gravity and Kullenberg cores we characterise the architecture and facies of the subbottom sediment. A total of six sedimentary facies types were observed, three of which represent the Pliocene - Holocene background sediment in the wider Nice area while another three are associated with the 1979 landslide and tsunami. The three primary facies types are soft silty clay/clayey silt, somewhat indurated silt/sand interbeds, and Pliocene conglomerates underlying the former. The three other facies are poorly sorted mass wasting deposits up to pebble size, silt representing the finer fraction of the mobilised mass, and a tsunami-related bed into which plant debris and artefacts got amalgamated.
\end{abstract}

Accompanying geotechnical results attest that significant strength variations exist when comparing measurements from the narrow shelf, shelf break and shallow slope as well as the 1979 slide scar. Factors such as groundwater charging in the more permeable horizons further lower the effective stress and, in places, approach lithostatic. Above such permeable silt/sand beds, deformation of soft clay is observed, suggesting that leaching of ions from the clay mineral surfaces and frayed edges also facilitates weakening and creep, micro-slumping and folding. Elevated water supply as well as hydraulic fracturing of the clayey sediment is further attested by pipes of $\mathrm{cm}$-diameter and several decimeters length, which entrained very soupy mud. In the shallowmost deposits in and landward of the slide scar, we also observe remnants from the catastrophic deposition associated with the 2-3 $\mathrm{m}$ high tsunami wave triggered in 1979, as attested by amalgamated sea grass and artifacts. Based on our observations and measurements on core-scale and earlier models based on in situ CPTu, we suggest that a significant part of the Quaternary delta and slope apron deposits are prone to being mobilised without a large external trigger, so that all in all a high risk for a landslide event of considerable size off Nice international airport is identified. 
Keywords : Soft sediment deformation, submarine landslide, weak zone, fluidisation

\section{Introduction}

There are regions on Earth where wide stretches of ocean margins provide evidence for mass flows at many scales and over a wide range of water depths (e.g. Maslin et al. 2004; Lee 2009). Spatially, slides are a global phenomenon occurring in fjords, river deltas and fan-canyon systems, open continental slopes and volcanic flanks (e.g. Huehnerbach and Masson 2004). Submarine landslides range greatly in their size, from small, frequently occurring failures in active environments such as coastal zones and canyons, to failures that involve hundreds of $\mathrm{km} 3$ of sediment but occur much more infrequently. Those 
megaslides (involving $>1000 \mathrm{~km}^{2}$ in area and several $100 \mathrm{~km}^{3}$ of sediment) are commonly related to gas hydrate dissociation (e.g. the Storegga slide off Norway [Solheim et al. 2005, and refs. therein], or examples along the North Atlantic margin [Maslin et al. 2004; Lee 2009]), and to volcanic flank collapses (Nuuanu slide off Hawaii [e.g. Morgan et al. 2003]; Canary islands [e.g. Masson et al. 2002]). In places, landslides represent a major geohazard for offshore infrastructure (platforms, pipelines, cables and submarine installations; e.g. Vaunat and Leroueil, 2002; Longva et al., 2003; Sultan et al., 2004) and, if tsunamigenic, to coastal structures and populations, both locally and in the far-field (Tappin et al. 2001).

In the North Atlantic sector (incl. the Nordic Seas and Mediterranean Sea), numerous large landslides have been reported for the past $45 \mathrm{ka}$, most likely associated with their proximity to massive Quarternary ice sheets (Maslin et al., 2004). The collation reveals that many events relate to periods of enhanced methane release (Preboreal and BøllingÅllerod periods) or to sealevel lowstand (i.e. correlation of slides with Heinrich events). Although Maslin et al. (2004) argue that the latter failures were driven by lowered hydrostatic pressure as a consequence of isostatic rebound and associated seismicity after the onset of deglaciation, an equally valid explanation could be that aquifer systems utilizing porous, horizontal to gently seaward-dipping delta/prodelta deposits from glacial time may have been maintained during deglaciation and associated increase in continental wetness, or alternatively may have stepped upward in the coastal sedimentary successions. One such area is the Ligurian Margin, whose French and Italian sectors represent slopes prone to hazardous failure and where scars in the seafloor bathymetry attest frequent collapses in the past. Risk assessment has hence been a major driver in research concerning the Ligurian slope, in particular after the October 1979 Nice avalanche and associated tsunami (e.g. Dan et al., 2007), but also because of the frequent flash floods along the French and Italian Rivieras (most recently with $356 \mathrm{~mm}$ precipitation in $6 \mathrm{hrs}$. and massive mudslides; November 2011). 
In this manuscript we focus on the failure mechanism of the slope south of Nice international airport and what could be learned from studying soft sediment deformational features in its vicinity. While earlier work addressed often in situ characterization of the material (e.g. Leynaud and Sultan, 2010; Stegmann et al., 2011; Steiner et al., 2015), we here look at the sedimentary facies, their typical internal deformation patterns, and their geotechnical properties as a function of mineralogy, physical properties and stress. Particular attention will be given to features that indicate sediment creep, slumping, shear or hydrofracturing/piping given that the study area is located adjacent to a major tributary from the western Maritime Alps, the Var river and delta. Governing geotechnical properties such as shear strength under static and cyclic load as well as permeability are utilised to assess how the various sedimentary facies are associated with vulnerability and potential slope failure in the future.

\section{Geological evolution}

\subsection{Geodynamic setting}

The Ligurian Sea is a $160-250 \mathrm{~km}$ wide basin in the western part of the Mediterranean Sea, which is characterised tectonically by the collision of the African and the Eurasian plates and the affects of the closure of the Tethyan Ocean and Alpine orogeny (e.g. McKenzie, 1970). The basin formed by marginal backarc extension during the Upper Oligocene-Miocene by a drifting-rifting episode related to the Alpine-Apennine orogeny behind the Apulian subduction zone (Rehault et al., 1984). Drift of the Corsica-Sardinian block and formation of the Appennines, the latter ranging until the early Miocene, are major consequences. The western margin is underlain by continental crust that is crosscut by pervasive faults of reverse or transgressive type, typically causing earthquake magnitudes < M2.2-4.5 (Rehault and Bethoux, 1984). Located within the southern subalpine fold and thrust belts (Arc de Nice and Arc de Castellane) (Laurent et al., 2000), 
the study area is characterised by presently still seismically active features such as the Peille-Laghet fault in the Maritime Alps (Courboulex et al., 2007) or the Marcel fault (Ai et al. 2014). The southwestward trace of the Peille-Laghet fault turns into the "Blausasc fault" (sensu Courboulex et al., 2007) and affects the area south of the city of Nice. The nearly E-W-trending Marcel fault is located further downslope at the Nice margin, but may equally affect slope stability in the Var canyon and adjacent slopes (Ai et al., 2014).

The basement of this margin is covered by $5-7 \mathrm{~km}$ of Miocene to late NeogeneQuaternary sediments consisting of conglomerates (the so-called "puddingstones", mud and marly ooze affected by frequent erosional events (Fahlquist and Hersey, 1969; Auffret at al., 1982; Savoye and Piper, 1991). Dubar and Anthony (1995) and Anthony and Julian (1997) carried out detailed sedimentary analyses including three representative stratigraphical sections of the Var, Paillon and Brague river mouths and found that the Var river mouth and 1979 Nice iㅏrport Landslide area (NAIL) are related to a Gilbert-type delta (Gilbert 1885, Savoye and Piper 1991, Dubar and Anthony 1995). This Gilbert-type delta was formed by the deposition of sediments from the western Alpine catchments of the Var river, which is characterised by high suspended sediment concentration, bedload transport, or deltaic sedimentary processes including wave reworking, geostrophic current, turbulent diffusion of seepage water in the basal aquifers and high density suspension flow of the fine-grained sediments (Anthony and Julian 1997). Reflectors are predominantly parallel to the seafloor with a southward dip, although some of the topset and foreset sequences are bent and dip towards the sea (i.e. in SSW direction; see Figs. 2c and 3). Quite interestingly, the aquifer charges the underground in a spatially diverse manner, this way creating lenses of significant excess pore pressure in the vicinity of Nice Airport and other areas in the Var catchment region (see details in Emily et al., 2010). 
Figure 1: Bathymetric map of the sector of the Ligurian Sea that contains the French and Italian Rivieras with the main canyon systems (Var, Paillon, La Roya). Note the location of the Nice Airport Landslide (NAIL) in 1979 and the pathway and travel velocities of the mobilised material.

There are major differences between the onshore and offshore lithostratigraphy near Nice. Onshore, the Pliocene "puddingstones" conglomerates are overlain by their eroded equivalent, i.e. Alluvial sandy gravel deposits, and both units extend into the Ligurian Basin (Figs. 1, 2). In contrast, however, the offshore sedimentary succession near Nice shows Holocene muddy laminates and, further seaward, Quaternary slope apron sediments intercalated with coarse units (alluvial gravel) or silt and delta foresets and topsets (e.g. Dubar and Anthony, 1995). One of the aims of this study is to map the different units and potential differences in sedimentary facies in more detail along selected transects across and nearby the 1979 Nice slide scar.

\subsection{Morphology and bathymetry}

The continental shelf of the French Ligurian margin is very narrow at $<3 \mathrm{~km}$ width, which tapers at the Baie des Anges and off the Nice airport to only a few hundred meters width. The shelf gradients of the outermost prodeltaic deposits are between $<1^{\circ}$ and $4^{\circ}$ (Cochonat et al. 1993, Mulder et al. 1994). The continental slope is very steep with an average slope angle of $11^{\circ}$ over the first $20 \mathrm{~km}$ from the coast and down to $\sim 2500 \mathrm{~m}$ depth. It is characterised by deeply-incised canyons generated by the Var and Paillon rivers with side-wall gradients up to $27^{\circ}$ (Fig. 2A, Pautot 1981, Klaucke et al. 2000, Ioualalen et al. 2010), and a large number of smaller steep-sided valleys, eroded surfaces, scars, ridges and gullies (Figs. 1 and 2A; see also Migeon et al. 2012 for detailed AUV bathymetry images). Based on high-resolution hull-mounted and AUV bathymetry data, 250 landslide scars were detected at the shelf break and on the upper continental slope between 20 and $1000 \mathrm{~m}$ water depth and were categorised as 
very small, small, medium or large scars (Migeon et al. 2012). The very small to small scars are semi-circular to ellipsoidal shaped and mostly located at the shelf break as well as along the crest and on the flanks of the interfluves/ridges. The dimensions vary between 30 and $150 \mathrm{~m}$ width and 2 to $30 \mathrm{~m}$ height; however, most failure planes are less than 10 m deep (Klaucke and Cochonat 1999, Migeon et al. 2012). This is supported by overconsolidated core material near sedimentary hiatuses, which indicate removal of 4$9 \mathrm{~m}$ of sediment (Cochonat et al. 1993). The medium and large scars are usually located in the deeper regions of the continental slope, except the medium sized scar of the 1979 NAIL event (Fig. 2A). The dimensions range from 150 to $500 \mathrm{~m}$ in width and 30 to $90 \mathrm{~m}$ in height (Migeon et al. 2012).

The Var River system and its torrential tributaries upstream are a fine example of a river channel system characterised by irregular episodes of high magnitude sediment cascades over short source-to-sink distances on a steep, increasingly densely developed coastal margin (Anthony and Julian, 1997). Onshore, the Var is a $135 \mathrm{~km}$-long river with a narrow valley throughout. The lower-valley gradient is moderate, at $4.3 \mathrm{~m} \mathrm{~km}^{-1}$, in the last $16 \mathrm{~km}$ down to the sea, where catchment lithologies are composed of various types of marls, sandstones and conglomerates (Anthony and Julian, 1997, 1999). The two most important lithologies in the lowermost valley are Pliocene conglomerates (also known as "poudingues" because of the large variety of $\mathrm{cm}$ - to dm-size pebbles in a sandy matrix) as well as the alluvial deposits, which largely represent the erosional product of the puddingstones (e.g. Guglielmi, 1993). This exploitation of the coarse grained Holocene fill of the Var valley, which acts also as drinking water reservoir, had serious consequences. The significant deepening of the channel caused a drop in the water table of the river and the unconfined aquifer. In order to refill the river bed small dams were constructed to retrain sediments. The coarse bedload remained behind the dams. However, this caused a change in sedimentation patterns at the river mouth and on the Nice Shelf because now only the fine-grained suspension load is transported to the coast 
and deposited on the submarine slope (Anthony and Julian, 1997, 1999).

The abovementioned stratigraphy of the Gilbert-type fan delta comprises two major aquifers: The upper one of Holocene age is defined by the fluvial channel gravel (i.e. Alluvial), which serve as a reservoir for an unconfined aquifer. The second lower aquifer consists of Pleistocene gravel directly overlying the Pliocene substratum (i.e. puddingstones) and is confined by a cap of thick intermediate shallow marine and deltaic impermeable mud (Anthony \& Julian 1997) (Fig. 2B, C). The gravle is believed to represent the direct erosional product of the puddingstones further landward and is hence of fluvial origin. The wedge of the fine-grained mud allows the landward merging of the two aquifers (Guglielmi, 1993; Anthony and Julian, 1997). The lower aquifer layer drains seaward down to a water depth of approximately $140 \mathrm{~m}$. There is a direct relationship between high discharge events like the abovementioned floods, flow through the alluvial aquifer and fresh water discharge into the sea (Guglielmi and Prieur 1997). Both precipitation in spring and late fall as well as snow melt in the Maritime Alps cause prominent peaks in river discharge (Guglielmi, 1993; Anthony 2007) as well as in the wealth of piezometers peppered over the wider Var valley and e.g., on the Nice airport premises. A synthetic cross section along the lower Var valley that illustrates the occurrence of the puddingstones across the coastline as well as the alluvial and marine deposits overlying it is given in Figure 2B.

Figure 2: (a) Map showing the landfill on which the Nice international airport was built (lighter grey). The port extension (darker grey) that collapsed on 16 October 1979 is projected above bathymetric data acquired after the event. (from Sultan et al., in press); (b) Stratigraphic section modified after Anthony and Julian (1997); (c) The tripartite stack of facies in the Var delta provides two aquifers which merge landward. The lower aquifer is confined in contrast to the upper one (modified after Dubar \& Anthony 1995). Locations of (b) and (c) are shown in (a); note also locations of Figs. 3a and 3b.

\subsection{The 1979 Nice Airport Landslide}


After a period of heavy rainfall, the Nice landslide occurred on 16 October 1979 on the Var prodelta, causing an embankment of the extended airport construction and underlying sediment to collapse and migrate downslope into the deep Ligurian basin. Based on bathymetry data the volume of failed material was estimated $\sim 0.0022 \mathrm{~km}^{3}$ near the airport and $\sim 0.0062 \mathrm{~km}^{3}$ in the mid-slope and displaced sufficient water to generate a tsunami wave of 2-3 m (Ioualalen et al. 2010). The resulting debris flow cut two submarine cables (ca. $2400 \mathrm{~m}$ and ca. $2600 \mathrm{~m}$ water depth; Fig. 1) some tens of kilometres away from the sliding area, corresponding to progressively decreasing transport velocities from $>50 \mathrm{~m} / \mathrm{s}$ in the steep slope, $36-43 \mathrm{~m} / \mathrm{s}$ in the Upper fan valley, $10 \mathrm{~m} / \mathrm{s}$ in the Middle fan valley, and 2-6 m/s when reaching the cables and entering the Lower fan valley towards the deep-sea (Mulder et al. 1997). Parts of the former embankment were transported to $>1000 \mathrm{~m}$ depth into the Var canyon. Shortly after the accident, a detailed investigation of the bathymetry was started (Pautot 1981) and several studies aimed to characterise the trigger mechanism(s). An external expert evaluation group (MIP, 1981) proposed retrogressive failure, which initiated at the slope and then retrogressively migrated towards the Nice coast and airport. Moreover, the tsunami wave following the slide lowered the sea level by $\sim 2.5 \mathrm{~m}$, which caused static liquefaction of the overloaded slope (e.g. Seed, 1988). Also, both the landfill operations for the airport extension some six month prior to the failure (see details in De la Tullaye 1989) and heavy rain (250 mm in 4 days) most likely caused considerable overpressure in the delta sequences. Given that both the extra loading of appx. 11 Mill tons of material and episodic rainfall (see http://www.hydro.eaudefrance.fr) were crucial factors destabilizing the slope, Dan et al. (2007) identified a combination of creep in the sensitive clay sediments on the Nice slope, loading by landfill material and embankment construction, and pore pressure rise owing to precipitation as main causes for the NAIL event.

Given the well-documented history of the 1979 Nice landslide, the wealth of both quasi- 
static and dynamic/episodic triggers and the large number of subsequent studies, the Nice slope represents an ideal laboratory to identify and quantify physical parameters governing landslide risk (see summary in Sultan et al., in press). The Nice slope has been suspected to be metastable in nature even before 1979 (Dan 2007), in particular because of the interplay between rapidly deposited delta sequences and groundwater movement. Recent work in the onshore portion of the Var aquifer that charges the Nice slope deposits unraveled that the alluvial deposits (80\%) and underlying Pliocene conglomerates $(20 \%)$ contribute significantly to the water recharge of the Var aquifer (Potot 2011). Groundwater charging in the lower Var valley and submarine strata lead to heterogeneous pore pressure anomalies and seepage, as attested by multi-level piezometers and other probes in the 1979 landslide scar (Stegmann et al. 2012). The geochemical variations over time reveal fresh water pulses in the more permeable of the marine sediments, which apparently cannot easily be linked to precipitation events. Not much is currently known about residence times of some of the alluvial groundwater (GW), but piezometer data on- and offshore suggest that some water is trapped in lenses and causes anomalously high pore pressures, e.g. beneath Nice airport (Emily et al. 2010). As has been shown using the marine in situ time series data, some of the marine sediments are at the edge of failure (Stegmann et al. 2011, their Fig. 10) and may cause a landslide of much larger volume than that of 1979. The aim of this paper is to regard the various sediment types in the Nice area and to assess to what extent they suffer soft sediment deformation and charging and hence could mobilise significant mass wasting volumes.

\section{Existing data base}

Given the catastrophic nature and anthropogenic component of the landslide and tsunami, the latter of which caused 8 casualties, a large number of investigations 
followed from 16 October 1979 onwards. We do not want to revisit them here, but refer to Sultan et al 2015 where the evaluation reports (MIP 1981; Seed et al., 1988) are discussed in much detail. Where appropriate, we will regard specific aspects of the reports when discussing our data in the light of potential future landslide risk below.

\subsection{Geophysical data}

During two geophysical surveys in 2000 and 2007, the Nice shelf and upper continental slope were mapped using a hull-mounted Simrad EM300 sonar system with a dominant frequency of $30 \mathrm{kHz}$ (see details in the Method section of Kopf et al. 2008). The swath bathymetric records were compiled to a Digital Terrain Model. The across-track resolution varies between 20 and $25 \mathrm{~m}$ according to the water depth (Dan et al. 2007, Kopf et al. 2008, Sultan et al. 2010). We were also looking at older (i.e. pre-1979) bathymetry data from the assessment reports of the NAIL accident to reconstruct the missing overburden by simply using the differential method.

As explained in section 2.2. above, the coastal zone in Nice is characterised by a narrow, oftentimes only a few 10 s of meters wide shelf before slope angles reach $5^{\circ}$ and more and dip steeply towards the Mediterranean Basin. When focusing into the region immediately south of the airport (Fig. 2A) it can be seen that the narrow shelf east of the Var river mouth is disrupted by a L-shaped depression, which is mimicking the geometry of the embankment which was built and subsequently destroyed in summer/fall 1979 (Bourillet et al., 1992). The inferred detachment surface was located in $27 \mathrm{~m}$ below seafloor, which is consistent with the differential bathymetry before and after the landslide where the average depth below the embankment is $30-35 \mathrm{~m}$ (see Fig. 6 in Dan et al. 2007). The maximum thickness of removed material was estimated to reach up to $55 \mathrm{~m}$ south of the embankment (Dan, 2007). 
During cruises M73/1 with R/V Meteor (Kopf et al., 2008) and the HALIGURE cruise (Henry and Migeon 2009), multi-channel (MCS) and chirp seismic reflection profiles were acquired in the region immediately south of Nice airport.

During R/V Meteor cruise M73/1, a Generator-Injector (GI) airgun with a chamber volume of 2 x $1.7 \mathrm{~L}(\sim 20-300 \mathrm{~Hz})$, a Mini-GI-Gun with a volume of $2 * 0.25 \mathrm{l}(\sim 30-400 \mathrm{~Hz}$ and a Micro-GI-Gun with a volume of $2 * 0.1 \mathrm{~L}(\sim 50-600 \mathrm{~Hz})$ were used as seismic sources. Data were recorded with a 50m-long 48 channel shallow-water streamer with single hydrophones.

The chirp sub-bottom profiler represents an efficient technique to image the shallow sub-seafloor sediment at high resolution but low penetration depth. During the HALIGURE cruise in 2009, 100 2D transects were recorded in the study area south of Nice airport using a profiler at 1.8 to $5.3 \mathrm{kHz}$ frequency, which is appropriate to achieve a decimeter-scale vertical resolution in shallow-water environments. Four hydrophones recorded the reflected waves. We have migrated the data using a p-wave velocity of $1500 \mathrm{~m} / \mathrm{s}$ in order to map prominent subbottom reflectors. Figure 3 shows seismic sections that illustrate the architecture of the shallow subbottom in the study area (see also interpretative drawing in Figs. 2B and 2C).

Figure 3: Seismic lines running roughly in N-S (MCS example at top) and NW-SE direction (Chirp example at bottom) across the narrow shelf and shallow slope off Nice. Note the 1979 NAIL scar in the Chirp example below. For location of the profiles, see Fig. 2A.

\subsection{Coring and sampling}

In 2001, four up to $17 \mathrm{~m}$ long Calypso cores were collected at the shelf break using the R/V Marion Dufresne (Sultan et al., 2004). This coring technique is highly effective in marine environments for recovering long sediment cores with minimum disturbance. The corer weighs 10 tons and consists of a $64 \mathrm{~m}$ long metal tube with a $14 \mathrm{~cm}$ diameter containing a high-pressure PVC liner with a $10 \mathrm{~cm}$ diameter. A mechanical trigger and a 
piston ensure uniform sampling of the sediment within the liner during the final freefall, from about $1 \mathrm{~m}$ above the seabed.

A total of 60 gravity cores with up to $5.3 \mathrm{~m}$ core recovery were collected at the shelf break and 1979 NAIL area using R/Vs Meteor and Poseidon (Kopf et al. 2008, 2009, 2012). Additional 12 Kullenberg cores were taken during subsequent STEP (Suivi TEmporel de la Pression interstitielle au large de l'aéroport de Nice) cruises operated by IFREMER. Both corers weigh 1.5-2.0 tons each and consist of a 2-6 m long metal tube containing an internal PVC liner with a 10 or $12 \mathrm{~cm}$ diameter (Emery and Dietz 1941). The cores were cut into sections of $1 \mathrm{~m}$ length, split, and generally underwent lithological description and pore water sampling, non-destructive MSCL (Multi sensor core logging using a Geotek device), vane shear and fall cone strength measurement and line scanning (high-resolution core photography) before discrete samples were taken for geotechnical and mineralogical analysis. The Multi Sensor Core Logging (MSCL) gamma density $(\rho)$ is $1.6-2.1 \mathrm{~g} / \mathrm{cm}^{3}$ for the upper continental slope (Cochonat et al. 1993, Sultan et al. 2004) and show higher values up to $2.2 \mathrm{~g} / \mathrm{cm}^{3}$ in the 1979 NAIL area (Dan et al. 2007). The compressional wave velocity $\left(v_{p}\right)$ is in the range of 1500 to $1700 \mathrm{~m} / \mathrm{s}$ (Sultan et al. 2004, Dan et al. 2007). Details concerning the methods used can be found in e.g., Kopf et al. $(2008,2009,2010)$. We summarise the lithological findings together with our analyses of facies and deformation patterns in Sections 5.1 and 5.2 below.

\subsection{Sediment physical properties}

In situ cone penetration data sets were collected using conventional onshore and offshore static-CPTu measurements as well as dynamic CPTu deployments (Steiner et al., 2015) and long-term data from an array of in situ probes (Stegmann et al., 2012). 
In 1994, five deep onshore static-CPTu measurements were performed along the shoreline of the Nice airport reaching down to $42 \mathrm{~m}$ penetration depth (Sols Essais, 1994; Dan 2007). Based on the CPTu data the sediments along the Nice airport are characterised as normally- to slightly overconsolidated clay with embedded thin beds of coarse sediments, except for the upper $5 \mathrm{~m}$ of engineering fill from land reclamation. Cone resistance of the hemipelagic deposits is low and reaches peaks when coarse layers (sand) are profiled whereas low values correspond to successions of sensitive clay (Sultan et al., 2004). In 2008, an additional nine offshore static-CPTu tests were carried out using the IFREMER Penfeld device (Sultan et al., 2008, 2010) to characterise the prodelta deposits and to identify and characterise potential shear zones. During the majority of the cruises run between 2007 and now, we also deployed the dynamic MARUM CPTu penetrometer (for details refer to Stegmann et al. [2006] and Steiner et al. [2015]). Approximately 120 short dynamic-CPTu tests were collected on the Nice upper continental slope, results of which are detailed in the cruise reports and in Steiner et al. (2015). With a few exceptions, the majority of the locations profiled show more or less uniform soft clayey silt with occasional peaks in resistance when thin beds of silt/sand or pebbles from the alluvial gravels were hit (see interpretation in Fig. 2B). Where relevant, we will revisit the in situ results in section 6 of this manuscript.

Laboratory techniques on sediment recovered near the Nice airport included measurement of Atterberg limits (BS 1377-2 1990, BS 5930 1999), grain size distribution (using a Coulter Counter LS-13320 following Syvitski, 2007), shear strength using various techniques (e.g., fall cone penetrometer, vane shear device, ring shear apparatus, oedometer), the latter methods being detailed in Blum (1997), Hansbo (1957), Bishop et al. (1972) or Terzaghi et al. (1996). Measurements were basically aiming at (i) understanding the strength properties, consolidation state and sensitivity of the surficial sediments, and (ii) utilise them for slope stability assessments. When regarding the slope apron, the clay content falls in the range of 16 to $30 \%$ with an 
average grain size of 20 to $30 \mu \mathrm{m}$ (Cochonat et al., 1993; Klaucke et al., 2000; Sultan et al., 2004). The proportion of sandy silt to sand in the coarse interbeds is up to $90 \%$. Rarely, gravel beds are found intercalated with the hemipelagic material (e.g. Dan et al., 2007) and are interpreted as alluvial. The alluvial pebbly deposits are derived from the Pliocene "puddingstone" conglomerates, which dominate wide portions of the onshore Var valley. With a dip direction towards the Ligurian Basin, they also underlie the marine Nice slope in several tens of meters subbottom depth (see Fig. 2C).

Based on the wealth of geotechnical data, various authors hypothesised that some of the material on the marine Nice slope is currently at the edge of failure, as e.g. attested by in situ pore pressures very close to the lithostatic load along certain horizons (Stegmann et al., 2011, their Fig. 10). In this paper we evaluate sediment facies characterisation and deformation patterns and compare them to governing geotechnical properties to assess the above hypothesis.

\section{Methods}

\subsection{Static deformation experiments}

The oedometer method is used to evaluate the deformation behaviour or compressibility of soil by increasing the axial stress on the sample. A cylindrical specimen of soil is enclosed in a metal ring in order to avoid lateral extension of the sample. This ensures a one-dimensional compression. The sample material is limited above and below by two porous disks to enable the dissipation of excess pore pressure during test procedure (Terzaghi et al., 1996). A total of four samples were tested following DIN 18135, where the load is doubled for each stress increment. The increment was maintained for 24 hours to ensure a completed consolidation phase and completely dissipated excess pore pressures. The change of height was measured 
during the consolidation process to determine the relationship between effective stress and void ratio. This relationship affords the determination of the preconsolidation pressure $\left(\sigma^{\prime} \mathrm{P}\right)$ of the sample material by using the graphical method of Casagrande (1936). To determine the over-consolidation ratio the effective overburden pressure had to be known. The overburden pressure was calculated by using the bulk density measured with the MSCL (see Kopf et al. 2009). The graphically determined preconsolidation pressure divided by the effective overburden pressure is the overconsolidation ratio (OCR). If the OCR is equal to 1 the soil is normally consolidated. A soil with an OCR $<1$ is under-consolidated and an OCR $>1$ stands for an over-consolidated soil specimen.

In order to determine the drained peak $\left(S_{P}\right)$ and residual $\left(S_{R E S}\right)$ shear strength under static conditions a direct shear apparatus (GIESA RS2) was used. This device consists of two stacked rings (circular inner surface is $40 \mathrm{~cm}^{2}$ ) whose contact should be in the middle of the specimen. Above and below the sample were two porous disks to ensure drainage during consolidation and shearing (Terzaghi et al., 1996). The apparatus allows a maximum confining pressure of $1250 \mathrm{kPa}$ and a maximum shear force of $25 \mathrm{kN}$. The maximum shearing distance is $22 \mathrm{~mm}$ which can be covered with a shearing velocity between $0.001-10 \mathrm{~mm} / \mathrm{min}$. The test procedure including sampling and sample assembly (undisturbed or remolded) was accomplished following DIN 18137-3. To calculate the Mohr-Coulomb parameters of the sample material a minimum of three tests for each sample under different confining pressures (50 kPa, $150 \mathrm{kPa}$ and $250 \mathrm{kPa}$ ) are required. The shearing velocity depends on the plasticity index (IP) of the material (DIN 18137-3). For the Nice sediments the velocity ranges between $0.008 \mathrm{~mm} / \mathrm{min}$ (for clayey soils) and $0.3 \mathrm{~mm} / \mathrm{min}$ (for deposits with high sand content). Materials were tested intact as well as remolded in order to also determine the sensitivity. For comparison, we ensured that all specimens of the remolded material featured the same initial density. During consolidation the specimens were kept submerged to ensure 
complete saturation.

\subsection{Dynamic triaxial experiments}

The MARUM dynamic triaxial testing device (DTTD) was used to determine the strength parameters of the undisturbed sample under cyclic loading. The apparatus consists of a servo-driven hydraulic cylinder, a hydraulic power unit, displacement-, load- and pore pressure transducers, a load frame, a pneumatically controlled confining and backpressure unit and a control station with a user interface to set up the spe-cific stress conditions (Kreiter et al. 2010). The device permits a maximum force of $25 \mathrm{kN}$. However, under dynamic conditions a maximum of $15 \mathrm{kN}$ at frequencies up to $50 \mathrm{~Hz}$ can be applied to the sample (Kreiter et al., 2010). The cylindrical specimens had a circular area of $0.001 \mathrm{~m}^{2}$ and a height of $75 \mathrm{~mm} \pm 3 \mathrm{~mm}$. The specimens were assembled in a Stenzel triaxial cell (for technical details refer to Wiemer et al. [2015]).

All seven samples tested were consolidated under an effective confining pressure of 100 $\mathrm{kPa}$ and a back pressure of at least $300 \mathrm{kPa}$. During consolidation under drained conditions the stress increments were increased in $10 \mathrm{kPa}$ steps. After each stress increment complete settlement of the specimen was awaited. This method was used to achieve a consolidation and satura-tion of the specimen as mild as possible to avoid disturbance. The saturation (B-value) of all samples was at least $95 \% \pm 2 \%$ (ASTM D 5311-92).

The specimens were subjected to cyclic loading at $100 \mathrm{kPa}$ effective confining pressure before a harmonic sinusoidal cyclic load was applied with a frequency of $1.0 \mathrm{~Hz}$. Kolymbas (2007) postulates a low frequency between $0.5-5.0 \mathrm{~Hz}$ to neglect effects of inertia inside the specimen. A single cyclic loading procedure with cyclic stress ratios (CSR) between 0.15 and 0.24 was used to test the different samples. The CSR is often used in cyclic failure assessment (Kramer 1996), defined as 


$$
\operatorname{CSR}=\frac{\sigma_{\mathrm{d}, \mathrm{cyc}}}{2 \times \sigma_{\mathrm{c}}^{\prime}}
$$

The deviatoric stress $\sigma_{d, c y c}$ exceeds or undercuts the confining pressure $\sigma_{c}^{\prime}$ with each cycle. The test cylinder simulates cyclic stresses until failure of the specimen takes place. During the testing procedure axial strain, vertical load $\left(\sigma_{n}\right)$, cell pressure $\left(\sigma_{c}\right)$ and pore water pressure were monitored and recorded (for more detail see Wiemer et al. 2015). Data analysis was carried out using the software MATLAB. There were two failure criteria. On the one hand an excess pore pressure of $90 \%$ of the effective confining pressure which means liquefaction of the soil (Kramer 1996); on the other hand, following the criteria for uniform cyclic loading proposed by Boulanger and Idriss, (2006), samples that did not liquefy were considered to have failed at $4 \%$ axial strain.

\subsection{Permeability experiments}

Permeability experiments were carried out in a backpressured apparatus following Darcy's approach. The head was applied hydraulically using an Envimeter pressure regulator. The same device is used to separately control the confining pressure in the permeameter's triaxial cell where core specimens with a diameter of $25 \mathrm{~mm}$ and height of $25-40 \mathrm{~mm}$ were placed. Specimens at different depth were loaded by their in situ effective overburden stress $\left(\sigma^{\prime}{ }^{\prime}\right)$ and coefficient of permeability $\left(\mathrm{k}_{\mathrm{f}}\right.$, here given in $\left.\mathrm{m} / \mathrm{s}\right)$ was calculated. A temperature correction was performed using a correction factor of 0.771 in order to convert the measurements at $20^{\circ} \mathrm{C}$ to parameters at $10^{\circ} \mathrm{C}$ (see BS 1377-6 1990 for details), which more closely resembles Mediterranean Sea bottom water conditions of ca. $13^{\circ} \mathrm{C}$. In total, we tested 8 marine minicores (both parallel and perpendicular to bedding) as well as 12 sandy matrix samples from the Pliocene puddingstones which show different degrees of cementation/alteration. 


\section{Results}

Our general approach in this study is (i) to describe the cores taken over the past 10 years and their depositional facies, (ii) to identify and interpret the deformational features in the material, and (iii) to measure a suite of geotechnical parameters on discrete samples from the cores to put us in order to assess the future risk of ongoing deformation, or even failure, in the various deposits at a given depth. What was done on each sample is generally shown in Table 1.

\subsection{Facies model}

A sedimentological description of gravity cores taken in strategic locations at the shelf and shelf break off Nice international airport spans from the shallowmost shelf $(\sim 15 \mathrm{~m}$ water depth) over the plateau to the shallow slope in order to obtain a composite profile through the uppermost tens of meters of slope apron sediment, including deposits related to the 1979 mass wasting event and tsunami. Five different facies were identified in the shallow subottom, which are illustrated based on a composite cross section dipping towards the south (Fig. 4). A sixth facies has also been considered since it underlies the marine laminated muds in places offshore (e.g. at the base of a $92 \mathrm{~m}$-deep drillhole at the edge of the failed airport embankment; M. Dubar, pers. comm., 2015). Owing to a lack of such samples from the gravity and Kullenberg cores, these conglomerates were sampled onshore where outcrops are numerous.

Figure 4: Schematic cross section running in NW-SE direction across the landslide scar south of Nice airport. Small bars illustrate the locations of gravity cores, which were utilised to have a composite profile of the upper few 10 s of meters for the facies analysis. Refer to text for detailed findings and interpretation (modified after Haas, 2011), and Fig. 2a for location of profile.

Facies I represents the most common deposit on the Nice Slope and is mainly derived from the suspension load of the river Var. Both sedimentological description 
and grain size analysis attest a clayey and silty composition, gradually ranging from silty clay to clayey silt (Fig. 5). From Atterberg testing it was interpreted as slightly plastic to medium plastic silty clay. The material is characterised by distinct color laminations, occasional organic debris (wood fragments) and shell fragments, bivalves and gastropods. The silty clay has a moderate sensitivity of 2 to 5 . Another characteristic of this facies is its high water content. The natural water content is generally very high, and occasionally exceeds the liquid limit (see section 5.3. and Tables 2,3 below). In addition to that, some cores provided evidence for horizons with small gas pockets. The gas originates from the decomposition of peat layers further down in the sedimentary succession (Sultan et al., in press).

Facies II is characterised by a varying grain size distribution from sandy silt to silty sand with a low clay portion. This facies interrupts the normal succession of facies I, but is not very abundant. The layers were deposited during periods with very high discharge or as a consequence of violent flash floods. Some layers are characterised by high water contents. Due to higher permeability compared to facies I they may act as aquifer. The fresh water in this aquifer may cause leaching of clay minerals in the surrounding silty clay, which in turn may cause an increase in sensitivity of the silty clay (see Dan et al. 2007, and geotechnical results further below).

Facies I and II represent the normal marine sedimentation on the Nice Slope. In the 1979 landslide scar and in direct vicinity three other facies could be identified:

Facies III is interpreted as the 1979 landslide debrite. It consists of pebbles or gravel in a matrix, which is characterised by variable grain size distributions from silty clay to medium sand (Fig. 5). The debrite is irregularly distributed in the scar. The boundary between facies III and I is an erosional contact, which was interpreted as the sliding surface. On a few occasions, gravel of alluvial origin was also found in this facies, however, since some of the pebbles contained traces of cement our interpretation is that 
they originate from land fill material, and not from geological formations such as the puddingstones or overlying Alluvial beds.

Facies IV is suggested to have been deposited soon after the 1979 slide and consists of homogenous silty clay. The material was deposited out of a suspension cloud which was generated by the slope failure, as is illustrated by the gentle gradation and subtle fining-upward. The facies was only found in cores located in the scar and it is homogenously distributed in the scar. A remarkable example is from GeoB13939 where $\sim 70 \mathrm{~cm}$ of homogeneous fall-out from the suspension cloud got deposited, into which in ca. $45 \mathrm{cmbsf}$ a plastic bag/foil got incorporated (Fig. 5).

Facies $\mathrm{V}$ is characterised by high contents of organic material (pieces of wood, bark and sea grass) and contains some anthropogenic material in an otherwise silty and sandy matrix with low clay contents. Interestingly, core GeoB13953 contained a piece from a plastic container with a September 1976 production date embossed into its inside. Such containers are usually used by local fishermen for flotation, so after appx. 3 years of use the „buoy" was apparently incorporated into the tsunami event layer with large amounts of seagrass and other natural materials and artefacts (see Fig. 5). The facies is located in $10-15 \mathrm{~m}$ shallow water in the vicinity of the coast and with only a few decimeters of overburden and was interpreted as tsunami deposit.

Facies VI somewhat falls out of the previous scheme since it represents a lithological unit not recovered in the gravity cores, but further below (and also further onshore): a series of massively banked, pebbly conglomerates of Pliocene age. These so called Puddingstones underlie the Quaternary marine deposits and, as is suggested from geophysical evidence of the highly reflective banks in MCS profiles, may reach the seafloor in places (see Kopf et al., 2008). Since our attempts to sample the conglomerates in the marine realm were unsuccessful, we worked on the onshore equivalent of the „Poudingues“ (Emily et al., 2010) because of their significance for the 
phenomena described in this manuscript.

Facies VI is also to be distinguished from the former five facies since the puddingstones are usually well cemented, or at least indurated deposits even when weathered/altered considerably, so that soft sediment deformational features are absent in subaerial exposures. Despite presumed differences offshore we include the massive puddingstone sequences in this study because of their moderately permeable matrix and important role in the confined, deep Var aquifer system. Earlier studies suggest that the upper $200-300 \mathrm{~m}$ of these conglomerates are water-saturated (Guglielmi, 1993). Beds are commonly dm- to m-thick and contain well to moderately sorted rounded pebbles of Alpine origin. Pebbles are sintered by a course cement rich in calcite (20-25\%) with a sandy texture (Salanon and Gandioli, 1988). Given the high permeability and difference in hydraulic head between Pliocene and overlying sediment/alluvium (ca. 30-60m), upward recharge is contantly taking place (Guglielmi and Mudry, 1996). We will revisit this aspect when regarding deformation features related to fluid overpressures.

Figure 5: Panel showing detailed photographs of the sedimentary facies I through V: Facies I (core GeoB13940) is the finest grained sediment in the study area, usually laminated silty clay. In contrast, Facies II (GeoB13946) contains coarser grained laminae and beds that may serve as permeable layers in the Var aquifer system. Compared to the two background sediment types, Facies III represents the debrite of the 1979 landslide, which may reach gravel-size in places (e.g. GeoB13929). Many of the layers are soupy since part of the fluid trapped during emplacement has not been drained over the past couple of decades. Facies IV represents the tsunami deposit into which clay to coarse sand, small rounded pebbles (example on the left, GeoB13953, 8-20 cm bsf) as well as plant debris such as seagrass is incorporated (example on the right; GeoB13953,

20-62 cm bsf). Note the peculiar plastic artifact with production date 09/76 embossed on it, which got amalgamated into the 1979 tsunami event layer when the wave hit the shallowmost portion of the shelf. Facies $\mathrm{V}$ is fine-grained mud (mostly clay and silt), which likely got deposited after the 1979 event out of the suspension cloud. In core GeoB13939 (appx. $27 \mathrm{~cm} \mathrm{bsl)} \mathrm{a} \mathrm{plastic}$ bag fragment got incorporated into the fall-out deposit. For details see P386 cruise report by Kopf et al. (2009).

\subsection{Deformation features}


Various types of deformation features are observed in the gravity and piston cores recovered offshore Nice. The majority of the cores were recovered from very shallow water depths of $50 \mathrm{~m}$ or less. The fine to medium grained deposits generally show identifiable sedimentary structures which include laminae (colour change, enrichment in organic matter, etc.), burrows from bioturbation, erosive structures and also mass movement deposits.

Most commonly, the clay mineral-rich deposits of Facies I show coloured laminations that range from grayish, olive and brownish colours all the way to reddish interlayers. Grading is usually normal. Individual layers are a few mm thick, but a given layer usually varies in thickness on the core scale. On numerous occasions, we observe wavy patterns and small steps (providing evidence for extensional deformation, with the steps being presumably oriented downslope), which do not fully disrupt the layers but thin them as a result of extensional (i.e. downslope) forces and creep (Figs. 6, 7). Sediments of Facies I are cohesive, have natural water contents of $30-46 \%$, plasticity indices ranging from $14 \%$ to $25 \%$ (Haas 2011), and do not show evidence for brittle failure. The silty clay is characterised as slightly to medium plastic and prone to creep.

Figure 6: Wavy clay with subtle, mm-sized vertical steps that indicate soft sediment deformation (A). In places, some mottling of the clay-rich deposits is found; often this is associated with small pockets of biogenic gas that disrupt the sediment (B). Photographs are taken on core GeoB13928, section 3 (A) and 1 (B).

Evidence for creep processes has been observed during ROV surveys (P. Henry, pers. comm., 2012), and progressive sediment deformation is also manifested by slump folds, sediment mottling and gentle folding of the cohesive subsurface sediments of mostly Facies I (e.g. Figs. 6B, 7A). Also, the small-scale stepping downslope, as observed fairly nicely in the coloured Facies I deposits (Fig. 7), attests that significant strain is accommodated without sediment failure to occur. This is reflected by slump folds on a decimeter-scale, by downward-stepping of the mm-thick layers owing to gravitational as 
well as episodic dynamic forcing, and by flow and mottling associated with variable fluid supply and pore pressure transients. We will revisit the preconditioning factors and short-term triggers for such features in the discussion below.

Figure 7: Examples of sediment facies I material that in many locations shows mottled claydominated layers of variable thickness, changes in colouration, and tilting and gentle (slump) folding or evidence for creep. Photographs are taken in the upper decimeters of cores GeoB13946 (A, B), GeoB12072 (C) and GeoB13952 (D).

More rigorous deformational events such as shear bands, small-scale normal faults and erosional surfaces are found in many of the cores, either within Facies I and II, or at the contact between these "background facies" and the event layers such as debrites from Facies III. While the latter certainly reflect mass wasting events of significant volume (e.g. the 1979 NAIL event or the associated tsunami deposit; see Fig. 5), the former may correspond to smaller amounts of shear displacement or downslope movement of small sediment volumes. Many of the contacts are sharp and the overlying deposit shows fining upward (see various layers in Fig. 8A)

Figure 8: (A) Erosional contacts in core GeoB13939, and (B) Facies II with normal faulting, potentially documenting small mass wasting events (core GeoB13929).

Characteristic for the reference core taken outside the 1979 scar (GeoB12072) are silty layers with high water contents, additionally releasing gas bubbles when cores were split (Fig. 9A). Such permeable water-rich coarse layers overlain by low-permeable clays are not only pathways in the shallowmost Var aquifer system, but also candidate planes of sediment failure since they allow high pore pressures to accumulate beneath low-permeability clay horizons. As a consequence, the effective stress on the samples in such loci will be lowered and eventually may cause failure. In places, piping has been found to hydraulically connect two granular layers all the way across decimeter-thick cohesive beds in between (see Weber, 2010, and Figs. 9C, D) 
For governing physical properties see Section 5.3 and the discussion below.

Figure 9: Soupy layers (A, B) and piping (C, D) that attest (at least temporary) charging of granular layers of the Var aquifer and the overlying and interbedded cohesive sediments, that rupture hydraulically. Panel A is from GeoB13929 (65-90 cm bsf), B from GeoB12072 (5-21 cm bsf), C is from GeoB13926 (141-177 cm bsf); D is a X-Ray CT image from GeoB13957 (160-255 $\mathrm{cm}$ bsf. Note that the gaps in the full core scan reflect earlier sampling for geotechnical experiments. See text.

\subsection{Geotechnical constraints}

Apart from the geotechnical experiments we performed on selected discrete core specimens, we routinely perform grain size analysis, Atterberg limits, Multi-Sensor Core Logging (MSCL) for bulk density, fractional porosity, p-wave velocity and magnetic susceptibility, and fall cone shear tests on a regular basis. Much of that is carried out on board and of low relevance here, but the reader is pointed to the cruise reports in case of interest (Kopf et al., 2008, 2009; Sultan et al., 2008). Where relevant, we cite some of the basic index properties from those routine measurements, but otherwise only report results from geotechnical testing on samples from cores shown in Figure 10.

Figure 10: Locations of gravity cores from cruises M73/1 and P410, which were used for this study. For the locations of other cores and measurements, refer to full cruise reports (Kopf et al., 2008, 2009).

The oedometer tests carried out served mostly to characterise the state of consolidation in places where removal of overburden as a consequence of the 1979 NAIL event were anticipated from the bathymetric depression south of the airport. We considered the differential bathymetry published by Dan (2007) from before and after the October 1979 landslide event and reconstructed missing overburden in Facies I in cores 
GeoB13925 and 13939, and also used Facies IV material (i.e. 1979 debrite) as a reference from these two cores. As documented in e.g. core GeoB13953, less than $10 \mathrm{~cm}$ of overburden are found on top of the 1979 event deposits (see Fig. 5, Facies IV). Facies IV has significantly higher void ratios, $10 \%$ higher water content and different stress paths when deformed in the oedometer (Table 2).

Given the load of the embankment built in 1979 and the lack of overburden on the 1979 deposits, we anticipated preconsolidation stresses of 330-460 kPa for Facies I samples in cores Geo13925 and 13939 in the NAIL scar (based on an assumed 33-46 m overburden from the differential bathymetry of Dan [2007] and Haas [2011]), but less than $10 \mathrm{kPa}$ for the most recent subseafloor deposits of Facies III and IV. However, results gave 520-640 kPa for Facies I, which corresponds to overconsolidation ratios (OCR) of 48-107, corresponding to removal of up to $40 \%$ more material than what is reconstructed from differential bathymetry (Dan, 2007; Dan et al., 2007). Similarly, we also measured OCRs in Facies IV that ranged around 10, which is an order of magnitude higher than normally consolidated sediment (our assumption given that no extra loading occurred since 1979) (see Table 2). One explanation for these elevated values in Facies IV is apparent overconsolidation, a phenomenon that has previously been described for this and other regions (e.g. Sultan, et al., 2000; Förster et al., 2010). In Facies I, the high values of OCRs may partly be owed to enhanced density of the reclamation and construction materials where gravel and concrete cements were heavily used. An alternative explanation may be seismic strengthening (see below).

Static direct shear strength was measured to quasi-statically assess which type of sediment is prone to intense sediment deformation and, eventually, failure. For this purpose we mostly focused on the primary facies (i.e. I and II) and not so much the deposits reworked during the 1979 event (i.e. III-V). Tests were run on cores GeoB13935 and -36 for Facies I and GeoB13935 for Facies II, all under reconstructed in situ effective normal stresses of 50, 150 and $250 \mathrm{kPa}$ see Table 3 for details). 
It can be seen from our results that for the majority of the samples friction angles and peak and residual strength are fairly similar, although cohesion is significantly lower in facies 2. Both the higher angularity and/or the elevated silt/sand content result in higher friction angles and less deformation in Facies II. The reason why frictional strength is also high in Facies I is probably the very thin nature of the clayey horizons, so that by taking discrete samples for the geotechnical tests, some silt was always incorporated into the intact cylinders of several centimeters height. As a consequence, our findings may overestimate the strength of Facies I materials, with the exception of sample GeoB13936, 20-24 cmbsf, where $\mu$ was 0.35 and cohesion was moderately high as a result of large portions of clay minerals (see Table 3).

Dynamic triaxial experiments were carried out to assess the vulnerability to liquefaction as a result of e.g. seismic activity. Naturally, one would predominantly expect this sediment response in facies II deposits because of their low cohesion and high content of granular (rather than cohesive) matter. The experiments were carried out on 7 samples (4 from Facies I and 3 from Facies II) with uniform cycles of deformation ranging from cyclic stress ratios of 0.151 to 0.245 and 11 to 283 cycles (Table 4).

The resistance to liquefaction of fine-grained cohesion-less soil (e.g. silt or silty sand) is lower with respect to cohesive soils with higher portions of fines (e.g. Facies I). These cohesive soils show a clay-like behaviour and respond to cyclic loading with cyclic softening (progressive failure). The liquefaction susceptibility of cohesive soils can be estimated by the plasticity index of the soil (Boulanger and Idriss, 2006), however, dynamic testing is more precise. The water content of the soil also plays a major role in liquefaction susceptibility. Our results attest that the Facies I specimens lie in the 'not susceptible'-area of Bray \& Sancio's (2006) liquefaction susceptibility chart and show progressive dilative behaviour instead of liquefying. Facies I has a higher shear strength under cyclic loading conditions than Facies II (Haas, 2011). The resistance to cyclic stress can be explained by the higher content of clay minerals, which increase the 
elasticity and plasticity of the soil. Because of that the kinetic energy generated by the movement of the piston during cyclic loading can be partly absorbed (Wiemer et al., 2015). For the Facies II specimens, two showed liquefaction, a fact that may be favoured by the interlayering of fine- and medium-grained layers, the latter of which may liquefy when the former act as low permeability-barrier and cause pore pressure to rise. We will revisit this aspect in the discussion.

Permeability measurements were carried out under backpressured conditions ranging from confining stresses of $25-100 \mathrm{kPa}$ for the shallow deposits from gravity cores and $400-2000 \mathrm{kPa}$ for the puddingstones (for nature of the material see Fig. 11A). The latter range of confining stresses was based on the assumed depth of burial underneath the NAIL scar from multi-channel seismic data acquired during cruise M73/1 (Kopf et al., 2008), which ranges around $50 \pm 25 \mathrm{~m}$ over wide parts of the shelf and upper slope offshore Nice. Hydraulic gradients of $20 \mathrm{kPa}$ and $100 \mathrm{kPa}$ were applied.

Our results attest that permeability is moderately low for Facies I and II given the shallow burial depth and fine- to medium-grained nature of the deposits. In fact, the coarser materials of Facies II are only twice as permeable as those of Facies I (see Fig. 11B and Table 5). Both Facies I and facies II samples show a fairly narrow range of permeabilities (Fig. 11B). Interestingly, the permeability of the much older, deeply buried and more indurated Pliocene conglomerates shows a wide range of values, namely from $1.59 \times 10^{-9} \mathrm{~m} / \mathrm{s}$, which is well within the results from Facies I, to values of $6.72 \times 10^{-12} \mathrm{~m} / \mathrm{s}$ (i.e. appx. 3.5 orders of magnitude lower) (Fig. 11B). Both from macroscopic observation and thin section analysis we relate the moderately low permeability of some of the puddingstones to their well-cemented matrix that results in a low porosity and hampered pathways for fluid migration. In turn, the altered puddingstone matrix is crumbly, shows authigenic clay mineral formation in places, and is most likely the result of repeated fluid charging by the Var aquifer. Recent 
geochemical studies attest this, because at least $20 \%$ of all Var aquifer water is accessing the puddingstones and not the overlying sediments and Alluvial deposits (Potot, 2011).

Figure 11: (A) Photograph of Pliocene conglomerates (so-called puddingstones) which shows $\mathrm{cm}$-sized clasts in a sandy matrix of variable alteration. Picture was taken at a surface outcrop near the village of Aspremont in the Var valley; (B) Results from permeability tests on discrete samples from Facies I, II, and puddingstones. See text.

Table 1: List of methods applied to the set of discrete samples that underwent geotechnical testing for this study.

Table 2: Results from oedometer testing and associated physical properties measurements.

Table 3: Results from direct shear testing and associated physical properties measurements.

Table 4: Results from dynamic triaxial testing using the DTTD (Kreiter et al. 2010).

Table 5: Results from permeability experiments on samples from facies I - VI.

In the discussion below, we will relate the governing physical and geotechnical properties of the main sedimentary facies offshore Nice to the various deformation features observed (see above), and also regard the other regional trigger mechanisms such as groundwater charging from precipitation and Var discharge as well as regional seismicity and anthropogenic impact. 


\section{Discussion}

In the discussion chapter, we first relate the findings from our facies analysis to the occurrence of deformational features and their abundance, intensity. We then relate them to the geotechnical parameters measured and the regional context, for instance by reviewing permeability results in comparison to time series data of precipitation and Var river discharge. Finally, other existing data from the NAIL region are used to assess past and future risk of slope failure based on our results.

From the findings of the facies analysis it has to be stressed that most of the deformational evidence is found in facies I, III and V, whereas there are rarely deformational structures observed in Facies II and IV, both silty and fairly homogeneous. Facies VI, the conglomerates, are not soft and hence excluded here. The three facies types with low to moderately intense deformation are different in the sense that facies I starts out as layered background sediment that undergoes progressive deformation while facies III and V represent event layers of the 1979 landslide (i.e. debrite) and tsunami and thus reflects a primarily chaotic nature with primary deformation features, respectively.

We first concentrate on the preconditioning of facies I and how the longer term regional forcing such as sediment creep (e.g. Dan et al., 2007, their Fig. 18) as well as the shortterm triggers such as groundwater (GW) pulses, earthquake tremor, and rapid sedimentary loading from natural and/or anthropogenic processes may intensify deformation all the way to faulting and slope failure. The evidence for soft sediment deformation is numerous from the cores we have recovered (e.g. Figs. 6-9) as well as accompanying field observations (Fig. 8B). If we relate the geotechnical results to features such as shear bands, stepping layers, slump folds, microfaults and pipes, the 
two governing parameters are the cohesive and frictional strength as well as the permeability.

Quite surprisingly, the shear strength data we get from Facies I and II are rarely very low ( $\mu \sim 0.44-0.51$, with only one sample at 0.35 ; see Table 1 ) and also show a minor difference between facies I and II. This result is consistent with a comprehensive ring shear study where a larger number of Nice slope sediments underwent high strain frictional experiments (Stegmann et al., 2014). There, the authors demonstrate that even samples with $>50 \%$ clay fraction have friction coefficients of 0.46 , whereas the coarser facies II deposits reach values of $\mu=0.76$ (26\% clay, $57 \%$ silt, $17 \%$ sand; see Stegmann et al., 2014 for details). Despite the fact that there is a good match in data between the different experimental techniques, it is also important to note that Stegmann et al. (2014) attested the clay mineral-rich deposits a high sensitivity, i.e. large ratio between peak and residual strength of the specimen. These authors argued that leaching of ions adsorbed to the clay minerals as a result of GW flow may be one possible mechanism to explain the high sensitivity (e.g. Moum et al., 1971; Torrance, 1975; Sakai et al., 2010). However, sensitivity values were found to be well below 30 , the value at which quick clay behaviour is anticipated (e.g. Torrance 1983). The assumption of leaching in some of the layers in the Nice offshore sedimentary sequence is supported by strong freshening of pore waters in some of our gravity cores (Kopf et al., 2010), in particular those taken in the 1979 NAIL scar. On one hand, we argue that the presence of GW is prevailing over wide parts of a given season, because we have found those freshened fluids during all the cruises we ran off Nice. On the other hand, however, active flow seems to be restricted to the periods of either heavy rain or enhanced Var river discharge after the snowmelt in the Maritime Alps. Evidence for this interpretation we gain from scuba diving measurements across the seafloor of the NAIL scar (Kopf et al., 2009) and also from long-term measurements using piezometers (Stegmann et al. 2011). Here, pore pressure values in certain layers serve as a proxy for GW charging and 
usually maintain on their ambient background values. After prominent precipitation events, however, pore pressures rise significantly in discrete horizons while other appear to be unaffected (see Stegmann et al. 2011, their Fig. 7A). As can also be seen from Figure 10 of the same authors are the consequences of elevated pore pressure transients, because in particular in the shallower levels the pore pressure values may equal or exceed those of the overburden stress. As a consequence the main precipitation periods (usually May and November of a given year) as well as the broad peak in elevated Var river discharge from October through June are times where the risk of slope failures is higher than usual.

Another potential cause for such a small mass wasting event could always be seismic forcing because microseismic activity of the area is high and larger earthquakes along the margin have also been reported for historic periods and the instrumented recent past (Courboulex et al., 2007; Larroque et al., 2009). In the wider study area, the Marcel and Blausasc faults (for location see Steiner et al., 2015, their Fig. 1B) represent the main candidates because of their proximity to Nice. There is no direct evidence for any connection between the 2012 mini-landslide or the 1979 NAIL event with earthquake activity, however, we argue that some of the deformational features in the sediment (e.g. the stepping layers or the piping; Figs. 8, 9, respectively) may well be associated with sudden charging of the water-saturated slope sediments. No evidence has been found to unambiguously distinguish between charging from aquifer and seismic loading to explain the stepping in layers, however, piping and soupy layers had been found at all times (i.e. when sampling during more than half a dozen cruises over the past 8 years) so that it seems likely that at least the Var aquifer is significantly controlling stability of the shallow Nice slope.

This conclusion is supported when quickly revisiting our dynamic triaxial tests and the obvious susceptibility of the Facies I and II deposits to liquefaction (see above and Table 4). At the same time, our contention is that seismic forcing may rarely be sufficient to 
trigger a major landslide south of Nice. Ai et al. (2014) calculated the risk of a shallow vs. deep-seated failure for the deeper Nice slope using both drained and undrained static and earthquake conditions and concluded that only in the dynamic (earthquake) case factors of safety become $<1$ (i.e. the slope may fail). However, even under drained or undrained earthquake conditions, a seismic event along the Marcel fault must have a magnitude larger than that of all known historical events. We would thus argue that moderate seismic activity in the study region is more likely to serve as a stabilising than destabilising factor. At active margins, significant earthquake shaking occurs with a rate of roughly $10 \mathrm{ky}^{-1}$ although micro-earthquakes are more frequent (Lomnitz 2004; Cisternas et al. 2005). At the Ligurian Margin, small to medium magnitude earthquakes occur frequently, but the majority is probably posing insignificant peak ground accelerations to the Nice area (Courboulex et al., 2007). Still, for a sediment layer in a few meters depth and sedimentation rates of between $8 \mathrm{~m} \mathrm{ky}^{-1}$ from 12-7 ky bp and 3.5 m ky-1 since then (Sultan et al., 2004), this layer may have experienced 10-100 Mw 4 earthquakes. All this energy may lead to seismic strengthening (Tokimatsu and Seed, 1987), i.e. a post-earthquake shear strength increase of a sediment through particle reorientation, compaction and inherent dewatering or drainage. As long as this layer is sufficiently close to the water-sediment interface to drain earthquake-induced excess pore water pressure, it will strengthen considerably. We feel that this process does not only explain the low abundance of truly pervasive faults such as those in Figure 8B, but may also be the more plausible explanation for overconsolidation ratios larger than what is anticipated in a normally deposited slope succession (see oedometer results in section 5.3 and Table 2). For the deposits with larger portions of granular silt and sand (e.g. Facies II, but also the coarser sections of Facies I), seismic strengthening is probably more likely than apparent overconsolidation to explain our oedometer results. In addition to seismic tremor, other sudden processes such as tsunami loading (as attested to be a contributing factor to the 1979 failure; see MIP, 1981), rapid sedimentary events 
or similar instantaneous stress changes are affected by the liquefaction susceptobility studied with the DTTD.

Finally, we want to discuss the hydrogeological regime based on the geotechnical findings, observed deformation features, and related results from earlier studies. As shown in Figure 11, the permeability measured is not unusual for both a shallow sediment or a (semi-) indurated conglomerate, however, if altered the permeability of Pliocene puddingstones is increasing. This is supported by a recently published study by Potot (2011) in which geochemical evidence led to an assumed partitioning of $\sim 80 \%$ of Var aquifer discharge through shallow sediment (alluvial onshore and marine soft deposits offshore) and $\sim 20 \%$ in the underlying puddingstones. We tested the conglomerate onshore outcrop samples under fully saturated conditions, so a comparison with the overlying marine Facies I - V materials seems acceptable for two reasons. First, the weathered specimens showed a loose, crumbly matrix which was impossible to mount into either the oedometer or triaxial/permeameter cell, so we effectively reconsolidated loose granular puddingstone matrix to their assumed original initial relative densities prior to permeability testing. Second, we note the highly reflective and layered nature of the top of the Pliocene conglomerates in marine multichannel seismic lines, including an inverse polarity relative to seafloor reflector in some lines and depth intervals (see Kopf et al., 2008, and e.g. Fig. 3A).

In order to explore how the observed permeabilities in the range of $10^{-9}$ to $10^{-10} \mathrm{~m} / \mathrm{s}$ affect soft deformation features such as pipes and soupy horizons with mottling, etc., we have to review the Var river discharge and precipitation over time. In October 1979 when the catastrophic landslide occurred, the Nice region experiences an all-time high in Var river discharge as a consequence of roughly a fortnight of heavy rain, and also elevated GW levels (see Sultan et al., in press, their Fig. 6C). Despite the fact that Dan et al. (2007) also argue about clay sensitivity and human forcing by the contruction activity of an embankment south of the airport, it is widely accepted that the dominant trigger 
mechanism was probably sustained flood discharge with a peak liquid flow of $1200 \mathrm{~m}^{3} \mathrm{~s}^{-}$ ${ }^{1}$ on the day of the event (i.e. 16 October 1979; see Anthony 2007). Such maxima in fluid discharge may be caused by either precipitation (as in 1979), snow melt, or a combination of both. Regional hydrologists established that the variable, but frequently enhanced flow rates cause pore pressure anomalies in excess of a few $\mathrm{kPa}$ in the Nice airport subbottom (Emily et al., 2010). Such elevated values are documented to be sustainable, which suggests that weakening of the clayey silt is more or less continuous over time and also substantial from both a physical and chemical point of view. Even when disregarding the leaching, which is a long-term process that may mainly result in creep, slump folds, and the likes, the physical forcing by applying substantial hydraulic gradients between either the granular and cohesive layers, or from one (more conductive) granular layer to the next (overlying) layer may cause the observed piping (Fig. 9). If higher permeabilities than what we measured are assumed, e.g. $2.6 \times 10^{-6} \mathrm{~m} / \mathrm{s}$ from Dan et al. (2007), steeper gradients and forcing may cause a different response, e.g. hydraulic failure at larger scale. This has been suggested from hydraulic gradients of 30 $60 \mathrm{~m}$ between the puddingstones and overlying deposits (Guglielmi and Mudry, 1996), which would favour charging of the overburden and hence a higher likelihood for piping and hydraulic failure in e.g. the marine muds. Such failures from both the anthropogenic loading by the embankment construction as well as the major precipitation event over the first half of October 1979 may have initiated the NAIL catastrophe. If all evidence from this and other studies are taken into account, this may well recur in the future.

\section{Conclusions}

An interdisciplinary approach using sediment facies analysis and deformation analysis was complemented by geotechnical measurements to characterise the suite of deposits in the region of the Nice Airport landslide from 1979 in order to shed light on the 
vulnerability of the area for future mass wasting. Our observations comprise not only abundant shear bands, slumps and microfolds, but also pervasive piping and gas voids that point towards hydrofracturing and other brittle deformation processes. Neighboring in situ data from earlier studies show that certain horizons are currently at the edge of failure (Stegmann et al., 2011), a finding that is indirectly supported by evidence for small mass wasting events at the shelf edge (Fig. 8B) and gas occurrence in seismic and CPTu data (Leynaud and Sultan, 2010; Steiner et al., 2015).

Although our data are restricted to the shallow subbottom portion offshore, we conclude that a landslide may not be restricted to those clayey deposits, but may originate at larger depths of up to $100 \mathrm{~m}$. The corresponding target horizon for such a failure may be the top of the Upper Pliocene puddingstones, a sequence of massive conglomerates that are currently subject to disaggregation into the alluvial deposits of the Var river system. Our measurements on the onshore puddingstones gave permeabilities similar to those for Facies I and II in the shallow subseafloor (see above and Fig. 11), and hence may favour significant fluid discharge and - potentially elevated pore pressures that may lower effective overburden stress . A landslide at this depth level (i.e. top of puddingstones) could mobilise up to 5-10 times more material than that of 1979 and would obviously have catastrophic socio-economic consequences for the coastal region.

\section{Acknowledgements}

This manuscript benefited from discussion among scientists and technicians from IFREMER Brest and MARUM too numerous to be named here, and scientific parties of the cruises cited. The work presented in this paper was funded by MARUM - Center for Marine Environmental Sciences, University of Bremen and in-kind contributions from the parties involved (Ifremer, CEREGE). 


\section{References}

Ai, F., Förster, A., Stegmann, S., Kopf A., 2014. Geotechnical characteristics and slope stability analysis of the deeper slope of the Ligurian margin, Southern France. Proceedings of the Beijing Landslide Forum, 6pp.

Anthony, E.J., 2007. Problems of hazard perception on the steep, urbanised Var coastal flood-plain and delta, French Riviera. Méditerranée 108: 91-97

Anthony, E.J., Julian, M., 1997. The 1979 Var Delta landslide on the French Riviera: A retrospective analysis. Journal of Coastal Research 13, 27-35.

Anthony, E.J., Julian, M., 1999. Source-to-sink sediment transfers, environmental engineering and hazard mitigation in the steep Var River catchment, French Riviera, southeastern France. Geomorphology 31, 337-354.

ASTM American Society for testing and Materials, 2004. Load controlled Cyclic Triaxial Strength of Soil. D 5311-92.

Auffret, G.-A., Auzende, J.-M., Gennesseaux, M., Monti, S., Pastouret, L., Pautot, G., Vanney, J., 1982. Recent mass wasting processes on the Provencal margin (western Mediterranean), Marine slides and other mass movements. Springer, New York, pp. $53-58$

Bishop, A.W., G.E. Green, V.K. Garga, A. Andresen, and J.D. Browns (1971), A new ring shear apparatus and its application to the measurements of residual strengths, Géotechnique, 21, 273-328.

Blum, P., 1997. Physical properties handbook: a guide to the shipboard measurement of physical properties of deep-sea cores, ODP Technical Note 26. 
Boulanger, R.W., Idriss, I. M., 2006 Liquefaction Susceptibility Criteria for Silts and Clays. Journal of Geotechnical and Geoenvironmental Engineering, 132 (11), 1413 - 1426.

Bray, J. D., Sancio R. B., 2006. Assessment of the Liquefaction Susceptibility of FineGrained Soils. Journal of Geotechnical and Geoenvironmental Engineering, 132 (9). $1165-1177$.

BS 1377-2, 1990. Methods of test for soils for civil engineering purposes, Classification tests. British Standard Institution.

BS 1377-5, 1990. Methods of test for soils for civil engineering purposes, Compressibility, permeability and durability tests. British Standard Institution.

BS 1377-6, 1990. Methods of test for soils for civil engineering purposes, Consolidation and permeability tests in hydraulic cells and with pore pressure measurement. British Standard Institution.

BS 5930, 1999. Code of practice for site investigations. British Standard Institution.

Casagrande, A., 1936. Determination of the preconsolidation load and its practical significance. Proceedings of the International Conference on Soil Mechanics and Foundation Engineering, Vol. III Harvard University, Cambridge, 60 - 64.

Cisternas, M., Atwater B.F., Torrejon F., Sawai Y., Machuca G., Lagos M., Eipert A., Youlton C., Salgado I., Kamataki T., Shishikura M., Rajendran C.P., Malik J.K., Rizal Y., Husni M., 2005. Predecessors of the giant 1960 Chile earthquake. Nature 437: 404-407

Cochonat, P., Bourillet, J.F., Savoye, B., Dodd, L., 1993. Geotechnical characteristics and instability of submarine slope sediments, the nice slope (N-W Mediterranean Sea). Marine Georesources \& Geotechnology 11, 131-151. 
Courboulex, F., Larroque, C., Deschamps, A., Kohrs-Sansorny, C., Gélis, C., Got, J., Charreau, J., Stéphan, J., Béthoux, N., Virieux, J., Brunel, D., Maron, C., Duval, A.M., Perez, J.-L., Mondielli, P., 2007. Seismic hazard on the French Riviera: observations, interpretations and simulations. Geophysical Journal International 170, 387-400.

Dan, G., 2007. Processus Gravitaires et Evaluation de la Stabilité des Pentes: Approches Géologique et Géotechnique. Application à la marge algérienne et à l'effondrement de l'aéroport de Nice en 1979. Université de Bretagne Occidentale, p. 365.

Dan, G., Sultan, N., Savoye, B., 2007. The 1979 Nice harbour catastrophe revisited: Trigger mechanism inferred from geotechnical measurements and numerical modelling. Marine Geology 245, 40-64.

De La Tullaye, M., 1989. Un aéroport gagné sur la mer: Nice-Côte d'Azur. Revue XYZ, 38: 43-45.

DIN Deutsches Institut für Normung e. V. (1999): DIN 18135 - Eindimensionaler Kompressionsversuch. Beuth Verlag GmbH, 10772 Berlin.

DIN Deutsches Institut für Normung e. V. (2002): DIN 18137-3 - Bestimmung der Scherfestigkeit, Teil 3: Direkter Scherversuch. Beuth Verlag GmbH, 10772 Berlin.

Dubar, M., Anthony, E.J., 1995. Holocene environmental change and river-mouth sedimentation in the Baie des Anges, French Riviera. Quaternary Research 43, 329343.

Emery, K.O., Dietz, R.S., 1941. Gravity coring instrument and mechanics of sediment coring. Geological Society of America Bulletin 52, 1685-1714.

Emily A., Tennevin G., Mangan, C., 2010. Etude hydrogéologique des nappes profondes de la Basse Vallée du Var. Conseil Général Alpes Maritimes, 53pp. (unpublished 
report)

Fahlquist, D.A., Hersey, J.B., 1969. Seismic refraction measurements in the western Mediterranean Sea. Bulletin of the Institute of Oceanography Monaco 67, p. 52.

Förster, A., Spiess, V., Kopf, A., Dennielou, B., 2010. Mass wasting dynamics at the deeper slope of the Ligurian Margin (Southern France). In: Mosher, DC., Shipp, C., Moscardelli, L., Chaytor, J., Baxter, C., Lee, H., and Urgeles, R. (eds.), Submarine Mass movements and their consequences IV. Advances in Natural and Technological Hazards Series, Springer: 67-78.

Gilbert, G.K., 1885. The topographic features of lake shores, Annual Report. U.S. Geological Survey: 75-123.

Guglielmi, Y., 1993. Hydrogéologie des aquifères plio-quaternaires de la basse vallée du Var (Alpes-Maritimes, France). Universite d'Avignon et des Pays de Vaucluse, 188pp.

Guglielmi, Y., Mudry, J., 1996. Estimation of Spatial and Temporal Variability of Recharge Fluxes to an Alluvial Aquifer in a Fore Land Area by Water Chemistry and Isotopes. Ground Water, 34: 1017-1023.

Guglielmi, Y., Prieur, L., 1997. Locating and Estimating submarine freshwater discharge from an interstitial confined coastal aquifer by measurements at sea: example from the lower Var Valley, France. Journal of Hydrology 190: 111 - 122.

Haas, S., 2011. Sedimentological and Geotechnical Characterization of the 1979 Nice Airport Landslide Area. Unpubl. M;Sc thesis, Univ. Bremen, 116pp.

Henry, P., Migeon, S., 2009. HALIGURE cruise report: Fiche technique de fin de campagne. 
Hühnerbach V., Masson D.G., 2004. Landslides in the North Atlantic and its adjacent seas: an analysis of their morphology, setting and behaviour. Marine Geology 213:343-362

Ioualalen, M., Migeon, S., Sardoux, O., 2010. Landslide tsunami vulnerability in the Ligurian Sea: case study of the 1979 October 16 Nice international airport submarine landslide and of identified geological mass failures. Geophysical Journal International $181,724-740$.

Klaucke, I., Savoye, B., Cochonat, P., 2000. Patterns and processes of sediment dispersal on the continental slope off Nice, SE France. Marine Geology 162, 405-422.

Kolymbas, D., 2007. Geotechnik - Bodenmechanik, Grundbau und Tunnelbau. SpringerVerlag, Berlin Heidelberg.

Kopf, A.J., and shipboard party, 2008. Report and preliminary results of Meteor cruise M73/1: LIMA-LAMO, Berichte aus dem Fachbereich Geowissenschaften der Universität Bremen, No. 264, p. 169.

Kopf, A.J., and shipboard party, 2009. Report and preliminary results of Poseidon cruise

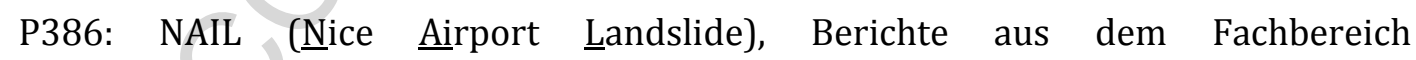
Geowissenschaften der Universität Bremen, No. 271, p. 161.

Kopf, A., Kasten, S., Blees, J., 2010. Geochemical evidence for groundwater-charging of slope sediments: The Nice airport 1979 landslide and tsunami revisited. In: Mosher, DC., Shipp, C., Moscardelli, L., Chaytor, J., Baxter, C., Lee, H., and Urgeles, R. (eds.), Submarine Mass movements and their consequences IV. Advances in Natural and Technological Hazards Series, Springer: 203-214.

Kopf, A.J., and shipboard party, 2012. Report and preliminary results of Poseidon cruise P429: MEDFLUIDS, Berichte aus dem Fachbereich Geowissenschaften der Universität Bremen, No. 286, p. 80. 
Kramer S.L., 1996. Geotechnical eartqhuake engineering. Prentice Hall, New Jersey

Kreiter S., Moerz T., Strasser M., Lange M., Schunn W., Schlue B.F., Otto D., Kopf A., 2010. Advanced Dynamic Soil Testing - Introducing the New Marum Dynamic Triaxial Testing Device. In: Mosher D.C., Shipp C., Moscardelli L., Chaytor J.D., Baxter C.D.P., Lee H.J., Urgeles R. (eds) Submarine Mass Movements and Their Consequences. Springer, Dordrecht, Heidelberg, London, New York, pp 31-42

Larroque, C., Delouis, B., Godel, B., Nocquet, J.-M., 2009. Active deformation at the southwest-ern Alps-Ligurian basin junction (France-Italy boundary): Evidence for recent change from compression to extension in the Argentera massif. Tectonophysics 467 (1-4), 22-34. 10.1016/j.tecto.2008.12.013.

Laurent, O., Stephan, J.F. and Popoff, M., 2000. Modalités de la structuration miocène de la branche sud de l'arc de Castellane (chânnes subalpines méridionales), Géologie de la France, 3, 33-65.

Lee, H.J., 2009. Timing of occurrence of large submarine landslides on the Atlantic Ocean margin. Marine Geology 264 (1-2), 53-64. 10.1016/j.margeo.2008.09.009.

Leynaud, D., Sultan, N., 2010. 3-D slope stability analysis: A probability approach applied to the nice slope (SE France). Marine Geology 269, 89-106.

Lomnitz, C., 2004. Major Earthquakes of Chile: A Historical Survey, 1535-1960. Seismological Research Letters 75: 368-378. doi:10.1785/gssrl.75.3.368

Maslin, M., Owen, M., Day, S., Long, D., 2004. Linking continental-slope failures and climate change: testing the clathrate gun hypothesis. Geology 32: 53-56.

McKenzie, D., 1970. Plate tectonics of the Mediterranean region. Nature 226, 239-243. 
Migeon, S., Cattaneo, A., Hassoun, V., Dano, A., Casedevant, A., Ruellan, E., 2012. Failure processes and gravity-flow transformation revealed by high-resolution AUV swath bathymetry on the Nice continental slope (Ligurian Sea). In: Yamada, Y., et al. (eds.), Submarine Mass Movements and Their Consequences. Springer, pp. 451-461.

MIP, 1981. Mission d'Inspection Pluridisciplinaire sur le sinistre de Nice du 16 Octobre 1979 - Rapport final. Unpublished report.

Moum, J., Löken, T., Torrance, J.K., 1971. A Geotechnical Investigation of the Sensitivity of a Normally Consolidated Clay from Drammen, Norway. Geotechnique, 21, 329-340.

Mulder, T., Tisot, J.-P., Cochonat, P., Bourillet, J.-F., 1994. Regional assessment of mass failure events in the Baie des Anges, Mediterranean Sea. Marine Geology 122, 29-45.

Pautot, G., 1981. Cadre morphologique de la Baie des Anges. Modèle d'instabilité de pente continentale. Oceanologica Acta 4, 203-212.

Potot, C., 2011. Etude hydrochimique du système aquifère de la basse vallée du Var: apport des éléments traces et des isotopes ( $\mathrm{Sr}, \mathrm{Pb}, \mathrm{d}^{18} \mathrm{O},{ }^{226,228 \mathrm{Ra}}$ ), Thèse de doctorat. Université Nice Sophia Antipolis, 240pp.

Rehault, J.P., Bethoux, N., 1984. Earthquake relocation in the Ligurian Sea (Western Mediterranean): Geological interpretation. Marine Geology, 55: 429-445

Rehault, J.-P., Boillot, G., Mauffret, A., 1984. The western Mediterranean basin geological evolution. Marine Geology 55, 447-477.

Sakai, T., Katsuyama, K., Md. Zakaria, H., Laura, J. P.N., 2010. Soil Mechanics (1)Fundamental Properties. Coronasha Publishing Co., Ltd., Tokyo.

Salanon, R., Gandioli, F., 1988. Cartographie floristique en grille et donnees geomorphologiques: L'exemple du reseau de vallons et de canyons des environs de 
Nice, Alpes Maritimes. Homenaje a pedro Montserrat, Spain, 743-745.

Savoye, B., Piper, D.J., 1991. The Messinian event on the margin of the Mediterranean Sea in the Nice area, southern France. Marine Geology 97, 279-304.

Seed, H., Seed, R., Schlosser, F., Blondeau, F., Juran, I., 1988. The landslide at the Port of Nice on October 16, 1979. Rep. No. UCB/EERC-88/10, Earthquake Engineering Research Center, University of California, Berkeley, CA.

Solheim, A., Bryn, P., Sejrup, H.P., Mienert, J., Berg, K., 2005. Ormen Lange-an integrated study for safe development of a deep-water gas field within the Storegga Slide Complex, NE Atlantic continental margin; executive summary. Marine Petroleum Geology, 22, 1-9.

Sols Essais, 1994. Rapport Interne. Sols Essais (unpublished data).

Stegmann, S., Kopf, A., 2013. How stable is the Nice slope? - An analysis based on strength and cohesion from ring shear experiments. In Krastel, S., et al. (eds.), Proceedings $6^{\text {th }}$ meeting of Submarine Mass Movements and their consequences, Springer: $189-200$.

Stegmann, S., Sultan, N., Kopf, A.J., Apprioual, R., Pelleau, P., 2011. Hydrogeology and its effect on slope stability along the coastal aquifer of Nice, France. Marine Geology 280, $168-181$.

Stegmann, S., Sultan, N., Pelleau, P., Apprioual, R., Garziglia, S., Kopf, A., Zabel, M., 2012. A long-term monitoring array for landslide precursors. A case study at the Ligurian Slope. OTC Proceedings, Houston April 2012, paper number OTC-23271-PP

Stegmann, S., Villinger, H., Kopf, A.J., 2006. Design of a modular, marine free-fall cone penetrometer. Sea Technology 47, 27-33. 
Steiner, A., Kopf, A., Henry, P., Stegmann, S., Apprioual, Pelleau, P., 2015. Dynamic cone penetration testing to assess slope stability in the 1979 Nice landslide area (Ligurian Margin, SE France). Marine Geology, 369: 162-181, DOI:

10.1016/j.margeo.2015.08.008

Sultan, N., and shipboard party, 2008. Prisme Cruise (R/V Atalante Toulon-Toulon; 2007): Reports and Preliminary Results, IFREMER Internal Report, Ref: IFR CB/GM/LES/08-11.

Sultan N., Cochonat P., Dennielou B., Bourillet J.F., Savoye B., Colliat J.L., 2000. Sur consolidation apparente et pression osmotique dans un sédiment marin. Comptes Rendus Acad Sci Paris - Earth Planet Sci, 331: 379-386.

Sultan, N., Cochonat, P., Canals, M., Cattaneo, A., Dennielou, B., Haflidason, H., Laberg, J., Long, D., Mienert, J., Trincardi, F., 2004. Triggering mechanisms of slope instability processes and sediment failures on continental margins: a geotechnical approach. Marine Geology 213, 291-321.

Sultan, N., Savoye, B., Jouet, G., Leynaud, D., Cochonat, P., Henry, P., Stegmann, S., Kopf, A.J., 2010. Investigation of a possible submarine landslide at the Var delta front (Nice continental slope, southeast France). Canadian Geotechnical Journal 47, 486-496.

Sultan, N., Voisset, M., Marsset, B., Marsset, T., Cauquil, E., Colliat, J.-L., 2007. Potential role of compressional structures in generating submarine slope failures in the Niger Delta. Marine Geology 237, 169-190.

Syvitski, J.P., 2007. Principles, methods and application of particle size analysis. Cambridge University Press, Cambridge. 
Terzaghi, K., Peck, R., Mesri, G., 1996. Soil mechanics in engineering practice. John Wiley \& Sons, New York.

Tokimatsu, B.K., Seed H.B., 1987. Evaluation of Settlement in Sands due to Earthquake Shaking. Journal of Geotechnical Engineering, 113 (8): 861-878

Torrance, J.K., 1975. On the Role of Chemistry in the Development and Behaviour of the Sensitive Marine Clays of Canada and Scandinavia. Canadian Geotechnical Journal, 12, 326-335.

Torrance, J.K., 1983. Towards a General Model of Quick Clay Development. Sedimentology, 30, 547-555.

Weber, K.-C., 2010. Abschätzung der Hangstabilität des oberen ligurischen Kontinentalhangs durch sedimentphysikalische Parameter. Master Thesis, Department of Geosciences, University of Bremen. 78pp.

Wiemer G., Moernaut, J., Stark N., Kempf P., De Batist M., Pino M., Urrutia R., de Guevara B., Strasser M., Kopf A., 2015. The role of sediment composition and behaviour under dynamic loading conditions on slope failure initiation: a study of a subaqueous landslide in earthquake-prone South-Central Chile. Int. J. Earth Sci., 1-19. 


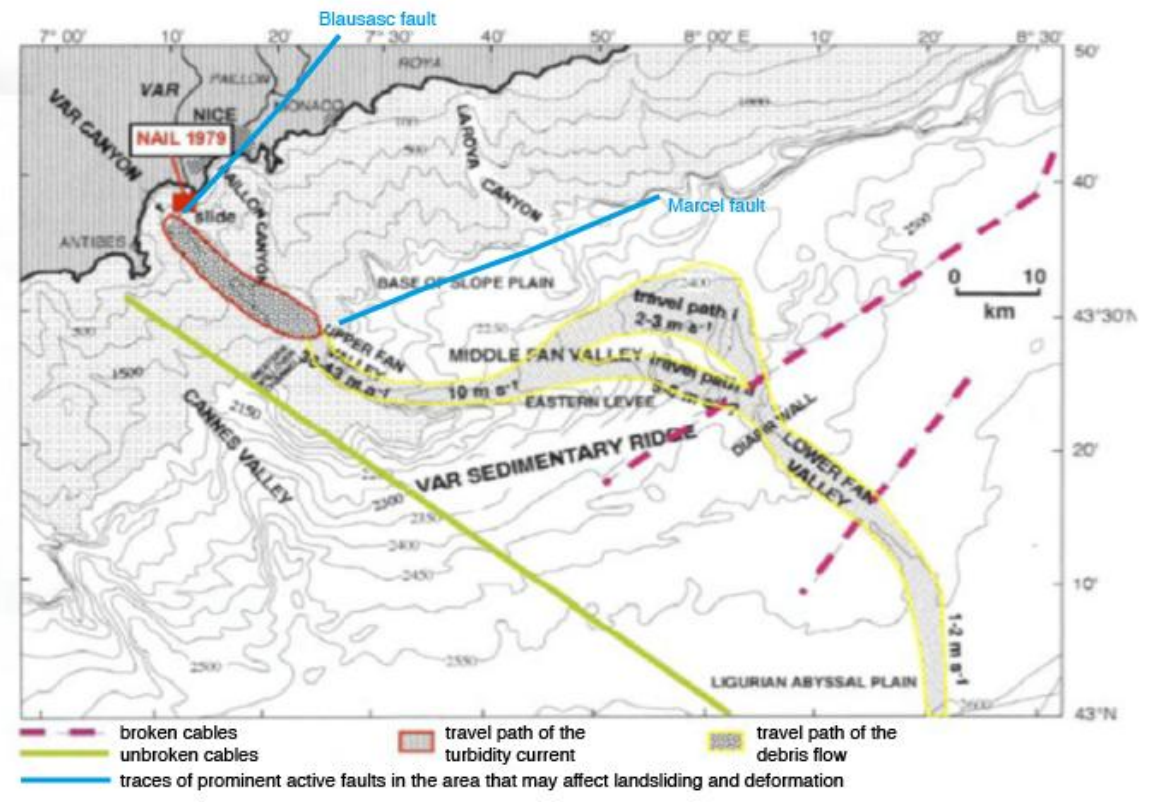

Figure 1 
a.
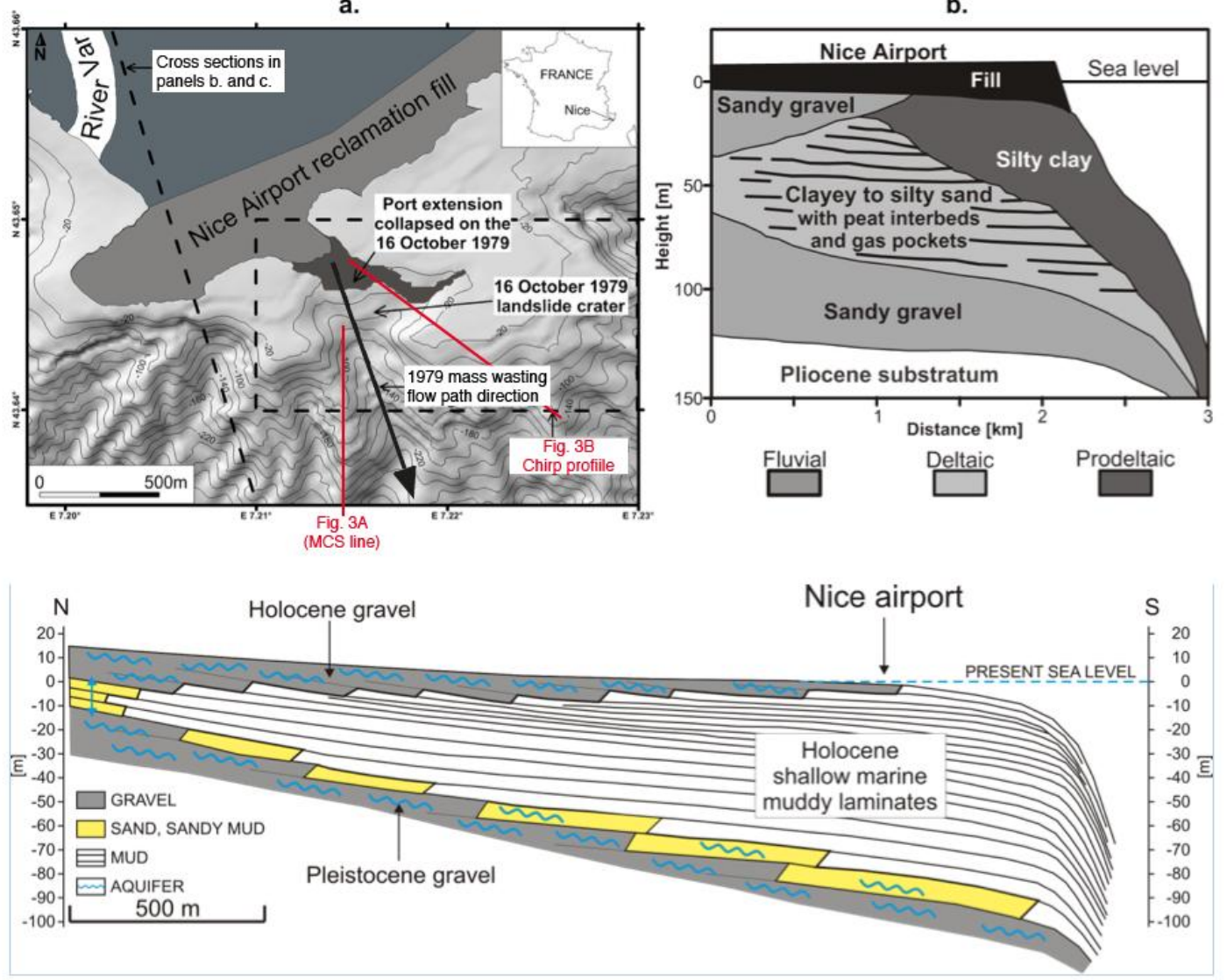

b.

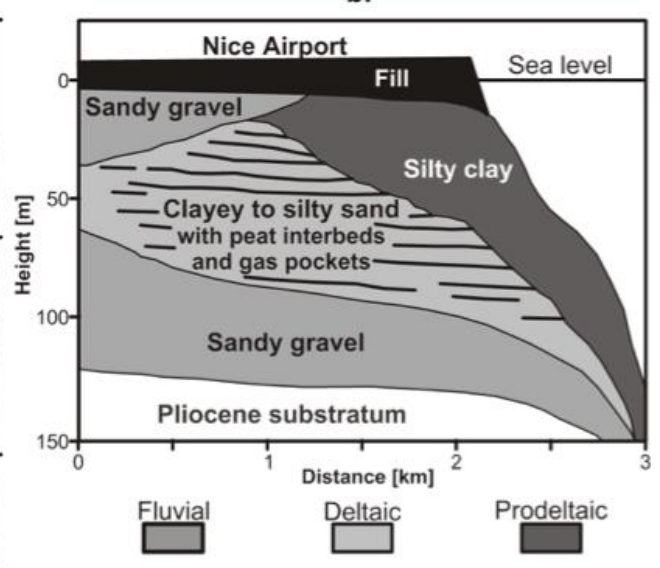

Figure 2 

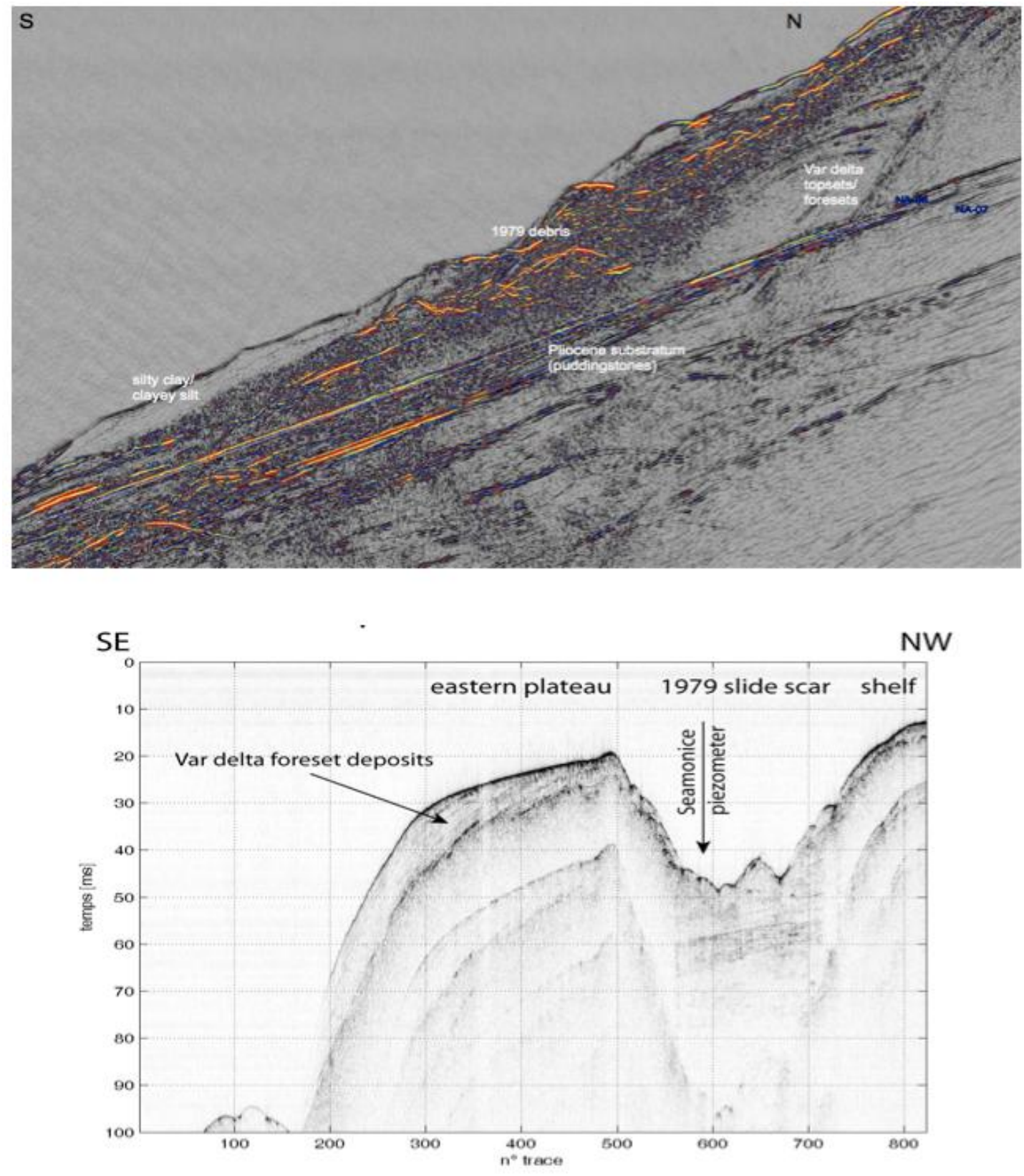

Figure 3 
a.

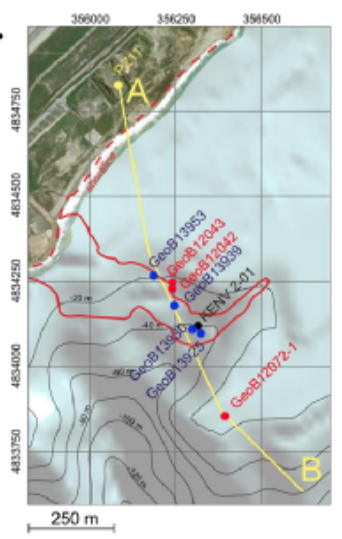

b. NW

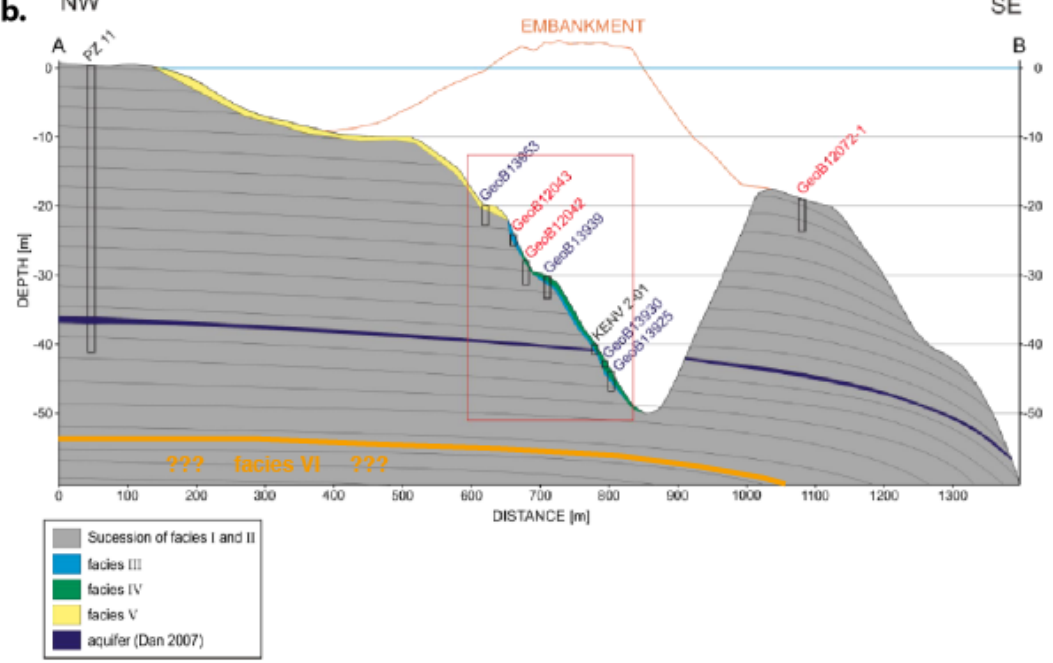

Figure 4 


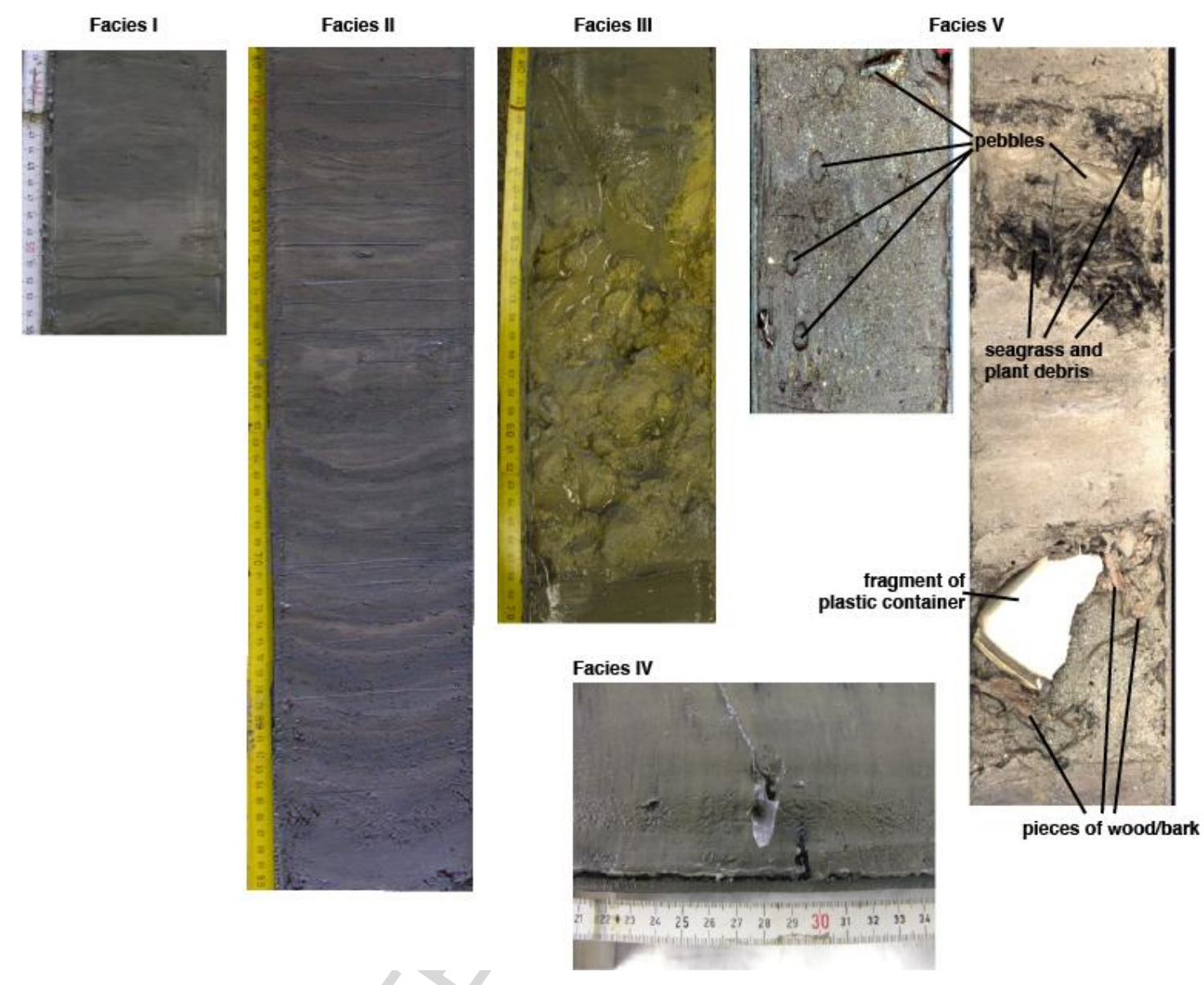

Figure 5 

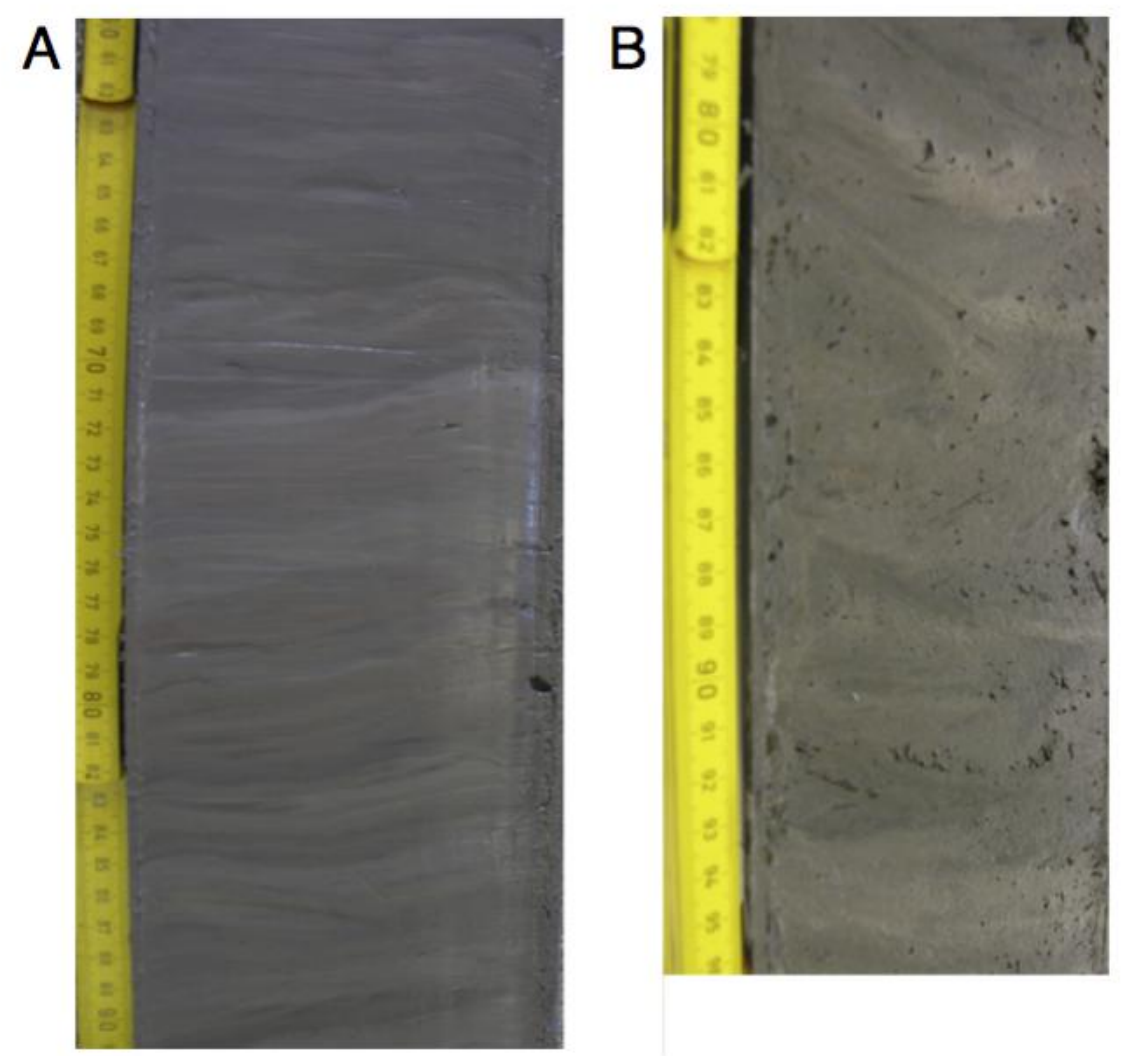

Figure 6 


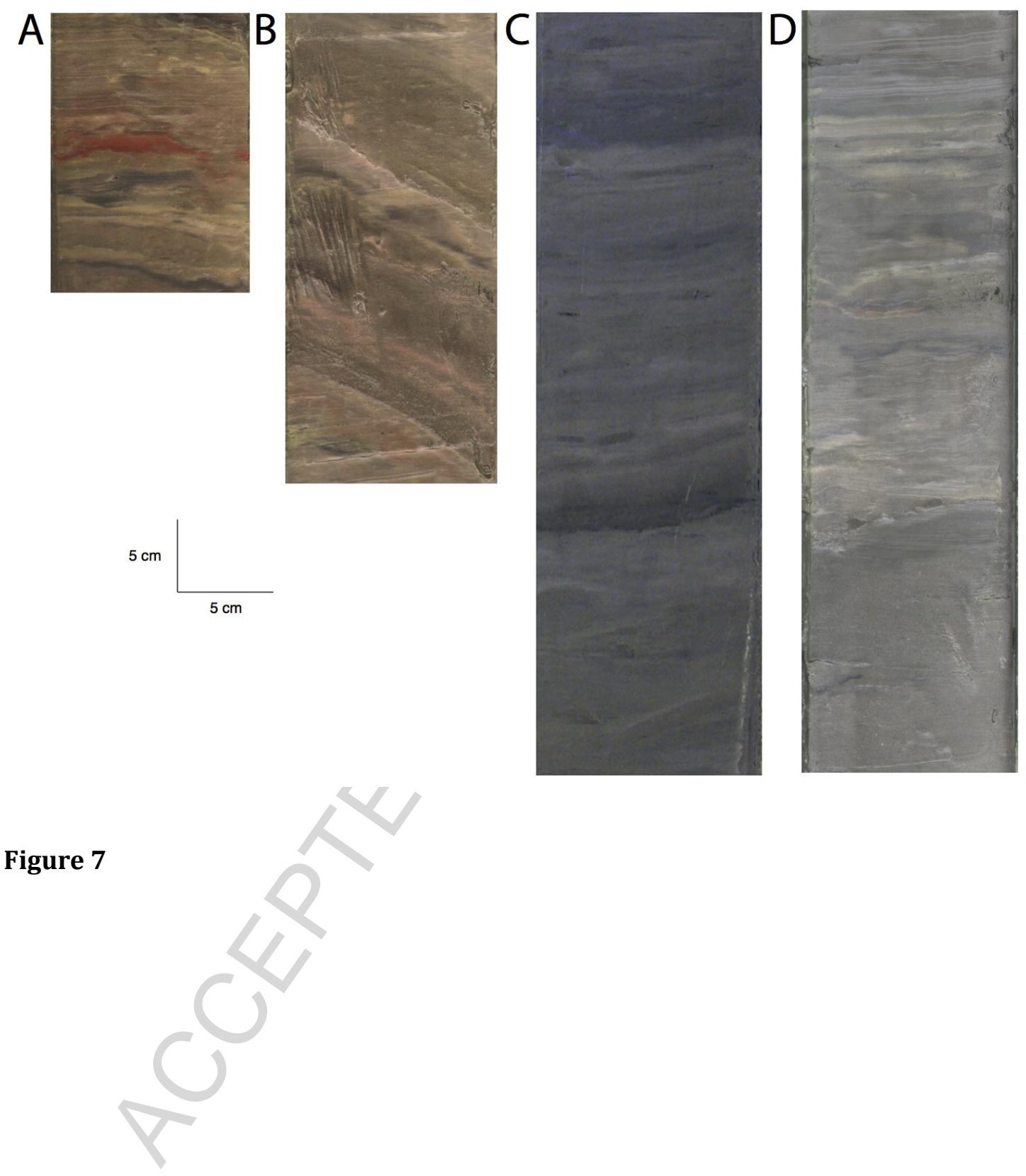




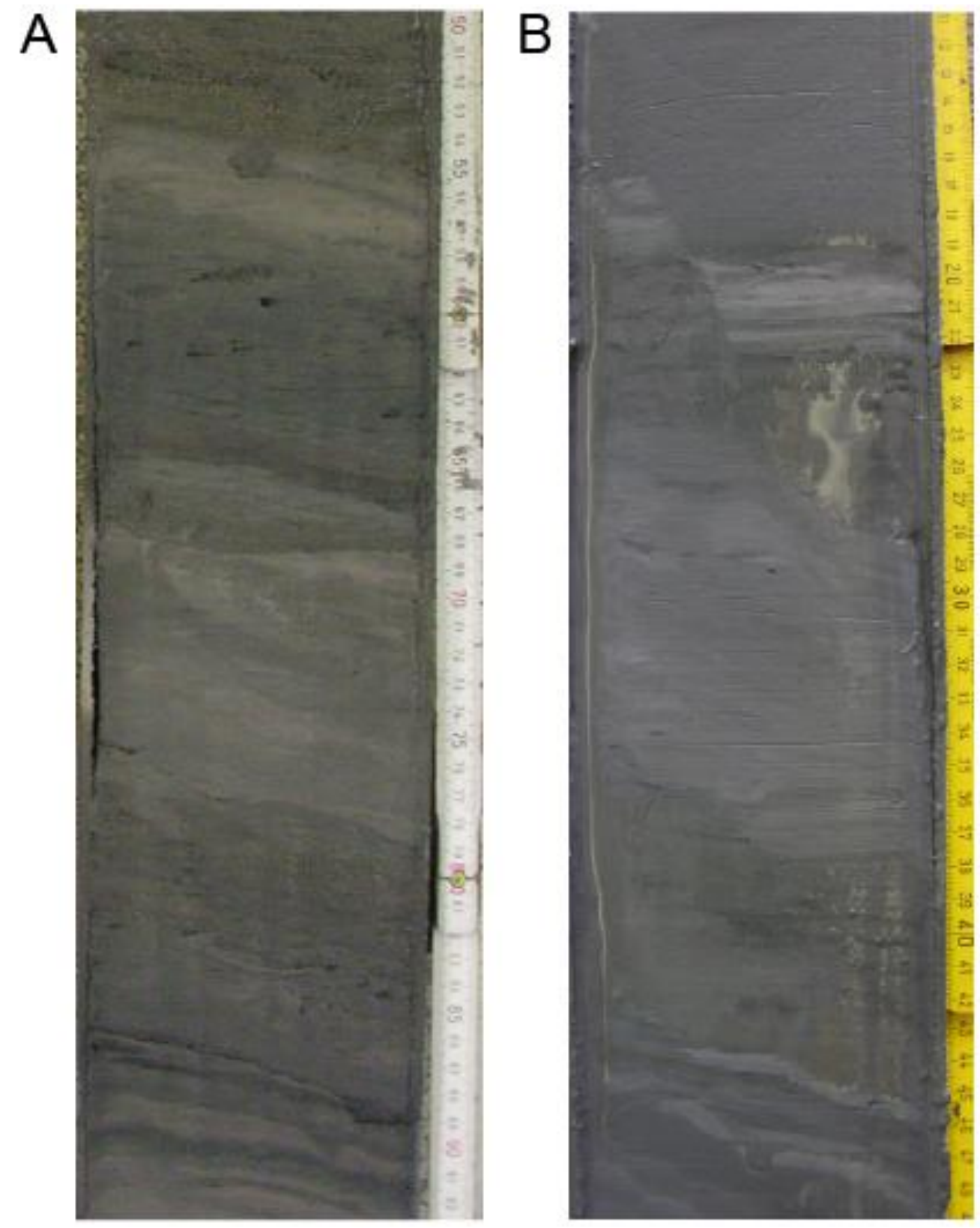

Figure 8 

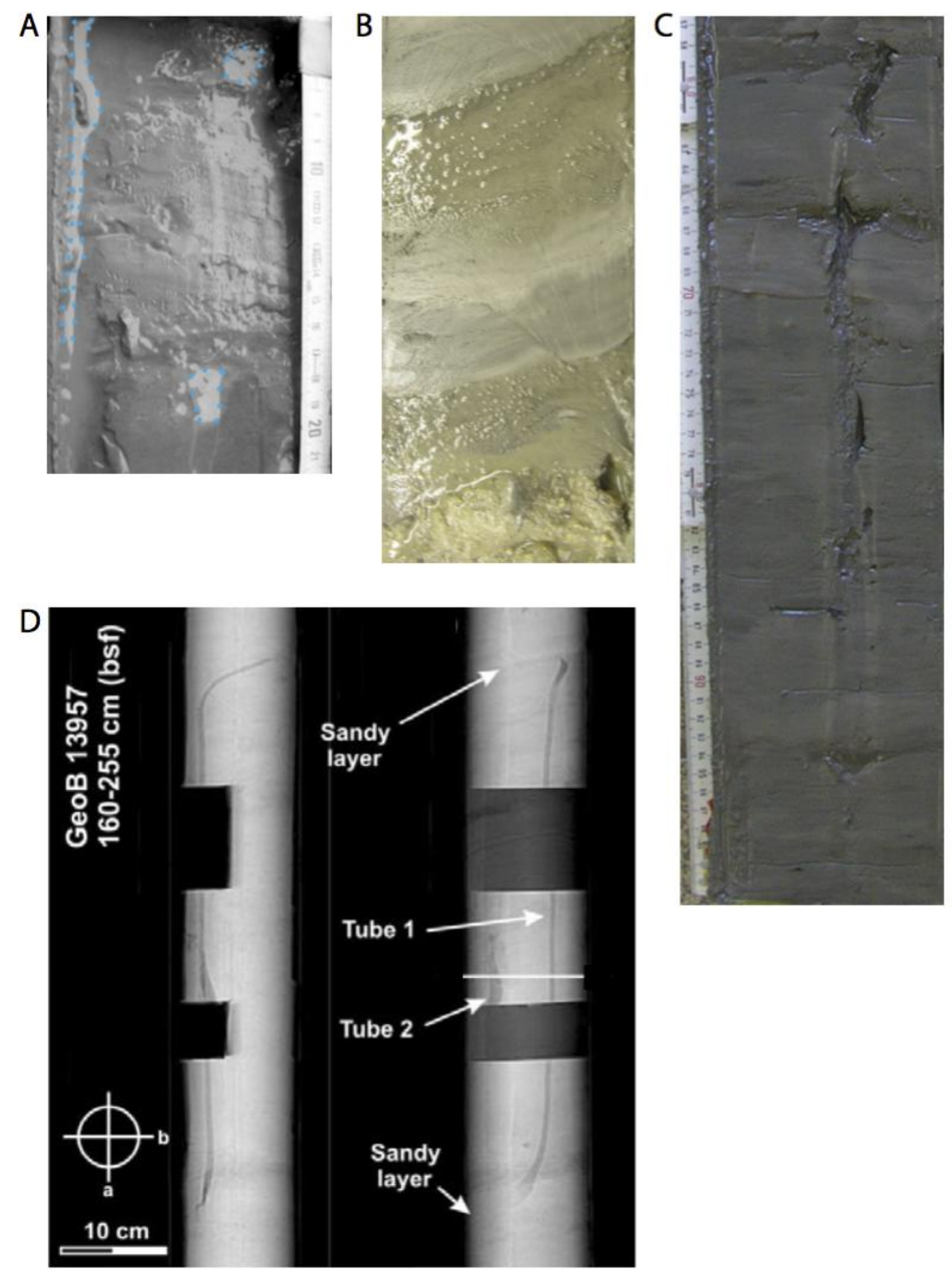

Figure 9 


\section{ACCEPTED MANUSCRIPT}

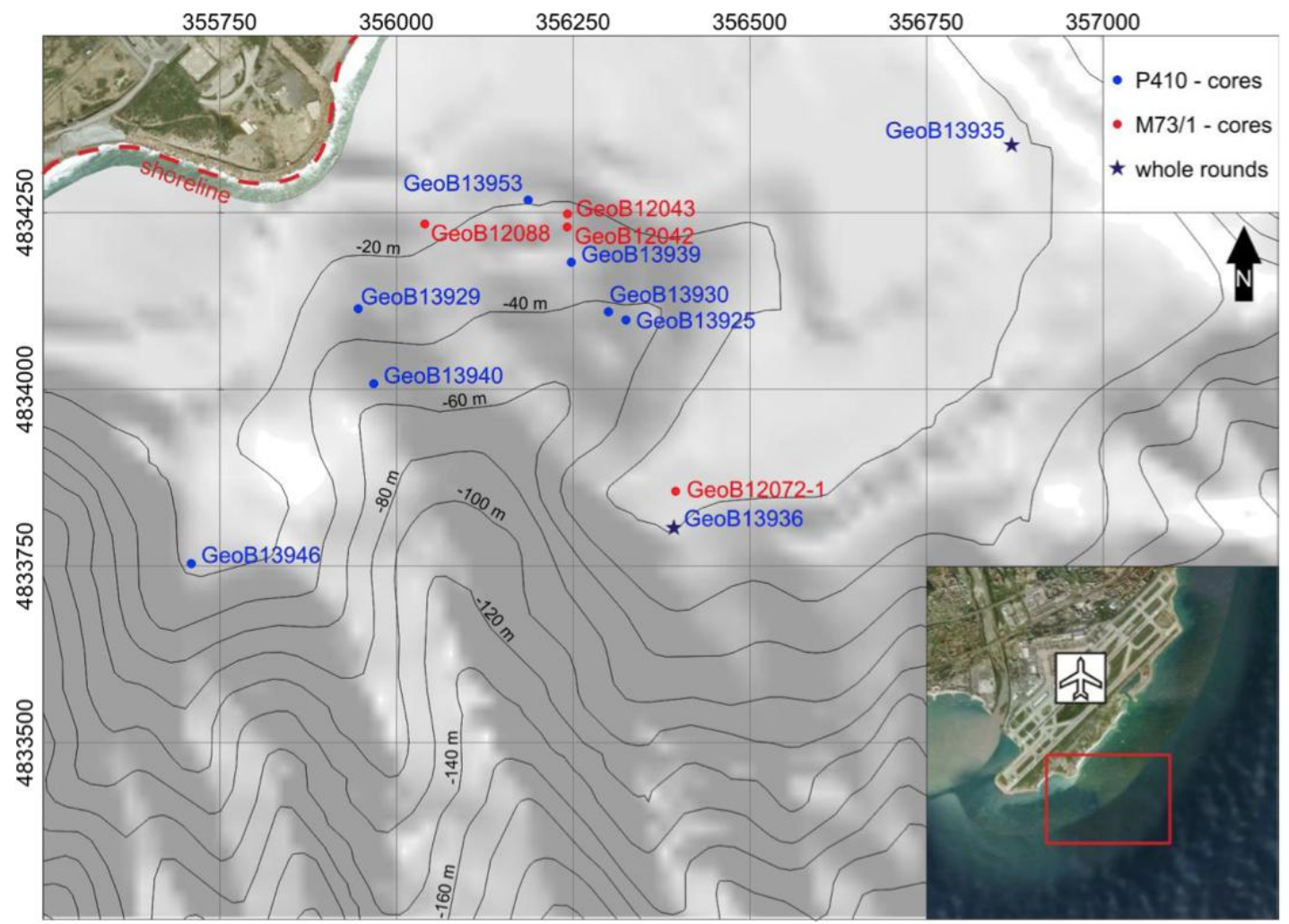

Figure 10 

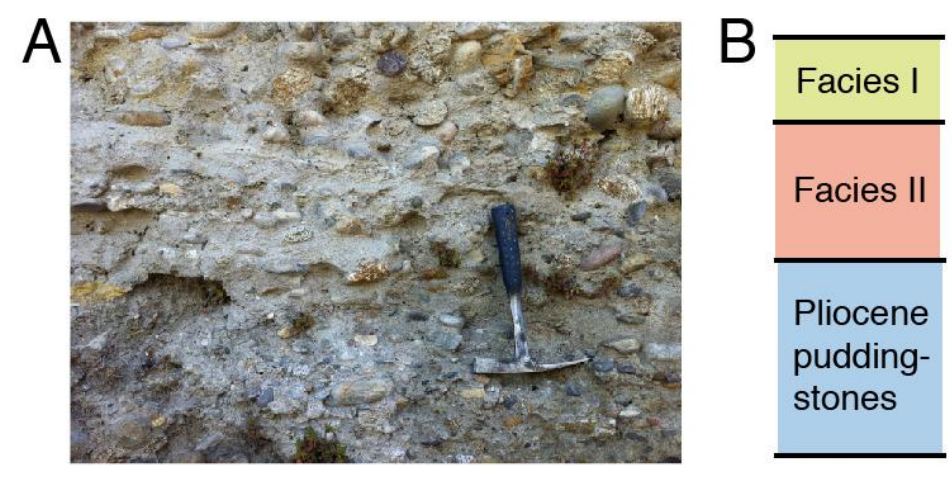

$1,35 \times 10^{-9} \mathrm{~m} / \mathrm{s}-$ $1,99 \times 10^{-9} \mathrm{~m} / \mathrm{s}$

$2,27 \times 10^{-9} \mathrm{~m} / \mathrm{s}-$ $2,72 \times 10^{-9} \mathrm{~m} / \mathrm{s}$

$1,59 \times 10^{-9} \mathrm{~m} / \mathrm{s}-$

$7,43 \times 10^{-10} \mathrm{~m} / \mathrm{s}$ (altered)

$2,48 \times 10^{-11} \mathrm{~m} / \mathrm{s}-$

$6,72 \times 10^{-12} \mathrm{~m} / \mathrm{s}$ (unaltered)

Figure 11 


\section{Table 1}

\section{ALL GEOTECHNICAL TESTS}

Core sample

GeoB13939_0.66 mbsf

GeoB13939_1.01 mbsf

GeoB13925_0.82 mbsf

GeoB13925_1.32 mbsf

GeoB13936_0.2 - 0.25 mbsf

GeoB13936_2.25 - 2.32 mbsf

GeoB13936_2.32 - 2.39 mbsf

GeoB13936_2.39 - 2.46 mbsf

GeoB13935_3.28- 3.33 mbsf

GeoB13935_3.33 - 3.38 mbsf

GeoB13935_3.50 - 3.55 mbsf

GeoB13935_2.81 - 2.90 mbsf

GeoB13935_2.81 - 2.90 mbsf

GeoB13935_2.81 - 2.90 mbsf

GeoB13936_2.46 - 2.58 mbsf

GeoB13936_2.46 - 2.58 mbsf

GeoB13935_3.38 - 3.50 mbsf

GeoB13935_3.38-3.50 mbsf

GeoB13935_2.81-2.90 mbsf

GeoB13935_2.81 - 2.90 mbsf

GeoB13935_2.81 - 2.90 mbsf

GeoB13957_3-1,6

GeoB13957_3-2,1

GeoB13957_4-2,8

GeoB13957_5-4,4

GeoB13958_6-5,2

GeoB13956_2-1,3

GeoB13956_2-1,8

GeoB13956_3-2,8

GeoB13956_5-4,4

4 unaltered puddingstone samples

7 altered puddingstone samples

\section{Method}

oedometer

oedometer

oedometer

oedometer

direct shear

direct shear

direct shear

direct shear

direct shear

direct shear

direct shear

direct shear

direct shear

direct shear

DTTD, CSR $=0.245$

DTTD, CSR $=0.158$

DTTD, CSR $=0.242$

DTTD, $C S R=0.212$

DTTD, $C S R=0.151$

DTTD, $C S R=0.201$

DTTD, CSR $=0.241$

permeameter

permeameter

permeameter

permeameter

permeameter

permeameter

permeameter

permeameter

permeameter

permeameter

permeameter 
Table 2

OEDOMETER

\begin{tabular}{|l|l|c|c|c|c|}
\cline { 3 - 6 } \multicolumn{2}{l|}{} & $\begin{array}{l}\text { GeoB13939 } \\
0.66 \mathrm{mbsf}\end{array}$ & $\begin{array}{l}\text { GeoB13939 } \\
1.01 \mathrm{mbsf}\end{array}$ & $\begin{array}{l}\text { GeoB13925 } \\
0.82 \mathrm{mbsf}\end{array}$ & $\begin{array}{l}\text { GeoB13925 } \\
1.32 \mathrm{mbsf}\end{array}$ \\
\cline { 3 - 6 } \multicolumn{2}{|c|}{} & Facis IV & Facies I & Facies IV & Facies I \\
\hline Water content (\%) & $\mathrm{w}_{\mathrm{i}}$ & 38.84 & 28.25 & 35.25 & 26.26 \\
\cline { 3 - 6 } Following DIN 18121-1 & $\mathrm{w}_{\mathrm{f}}$ & 22.42 & 18.58 & 21.65 & 17.83 \\
\hline
\end{tabular}

\begin{tabular}{|l|l|l|l|l|l|}
\hline Dry density $\left(\mathrm{g} / \mathrm{cm}^{3}\right)$ & $p_{\mathrm{d}}$ & 1.68 & 1.80 & 1.70 & 1.82 \\
\hline
\end{tabular}

\begin{tabular}{|l|l|l|l|l|l|}
\hline Specific gravity & $\mathrm{g}_{\mathrm{s}}$ & 2.69 & 2.70 & 2.69 & 2.69 \\
\hline
\end{tabular}

\begin{tabular}{|l|l|l|l|l|l|}
\hline Void ratio & $\mathrm{e}_{\mathrm{i}}$ & 1.06 & 0.81 & 1.01 & 0.71 \\
\hline \multirow{2}{*}{} & $\mathrm{e}_{\mathrm{f}}$ & 0.60 & 0.50 & 0.58 & 0.48 \\
\cline { 2 - 6 } &
\end{tabular}

\begin{tabular}{|l|l|l|l|l|l|}
\hline Porosity (\%) & $n_{i}$ & 51.49 & 44.74 & 50.26 & 41.49 \\
\hline & $n_{f}$ & 37.62 & 33.41 & 36.79 & 32.40 \\
\hline
\end{tabular}

\begin{tabular}{|l|l|l|l|l|l|}
\hline Overburden pressure (kPa) & $0^{1}$ insitu & 4.02 & 6.06 & 8.16 & 10.75 \\
\hline
\end{tabular}

\begin{tabular}{|l|l|l|l|l|c|}
\hline Preconsolidation pressure $(\mathrm{kPa})$ & $\mathrm{O}^{1} \mathrm{p}$ & 46 & 645 & 138 & 518 \\
\hline Over-consolidation ratio & OCR & 11 & 107 & 17 & 48 \\
\hline
\end{tabular}

$i=$ initial, before test

$f=$ finale, after test 
Table 3

DIRECT SHEAR EXPERIMENTS

Plasticity index

(\%)

$\leqq 25$

25 to 40

$>40$

\section{Shearing velocity $\mathrm{mm} / \mathrm{min}$}

0.04

0.008

0.002

\section{Series 1 samples}

\section{GENERAL INFORMATION}

\begin{tabular}{|llcl|}
\hline Apparatus & GIESA mbH RS2 Rahmenschergerät & & \\
\hline Frame & Consists of two stacked rings & & \\
& $\begin{array}{l}\text { sample height } \\
\text { circular surface area }\end{array}$ & 25.00 & $\mathrm{~mm}$ \\
& Facies I & 40.00 & $\mathrm{~cm}^{2}$ \\
\hline Sample & undisturbed & \\
\hline Shear velocity v: & GeoB13935_3.28-3.33 mbsf_(1) & 0.008 & $\mathrm{~mm} / \mathrm{min}$ \\
& GeoB13935_3.33-3.38 mbsf_(2) & 0.04 & $\mathrm{~mm} / \mathrm{min}$ \\
& GeoB13935_3.50-3.55 mbsf_(3) & 0.04 & $\mathrm{~mm} / \mathrm{min}$ \\
\hline
\end{tabular}

$\mathrm{w}_{\mathrm{i}}$ - Initial water content (before

test)

$\mathrm{W}_{\mathrm{f}}$ - Finale water content (after test)

$\mathrm{w}_{\mathrm{L}}$ - Liquid limit

$\mathrm{w}_{\mathrm{p}}$ - plastic limit

$\mathrm{I}_{\mathrm{p}}$ - plasticity index

$\mathrm{I}_{\mathrm{c}}$ - consistency index

$\mu$ - coefficient of internal friction

$\varphi$ - angle of internal friction

c' - cohesion

\begin{tabular}{|c|c|c|c|c|c|c|c|c|}
\hline \multirow[t]{2}{*}{ SAMPLE } & \multirow{2}{*}{$\begin{array}{l}\text { SOIL TYPE } \\
\text { following DIN 4022-1 }\end{array}$} & \multirow[t]{2}{*}{$\begin{array}{l}\text { SOIL GROUP } \\
\text { following DIN } 18196\end{array}$} & \multicolumn{2}{|c|}{$\begin{array}{l}\text { WATER } \\
\text { CONTENT } \\
\text { following DIN 18121- } \\
1\end{array}$} & \multicolumn{4}{|c|}{ ATTERBERG LIMITS } \\
\hline & & & $w_{\text {i }}(\%)$ & $\mathrm{W}_{\mathrm{f}}(\%)$ & $\mathrm{WL}_{\mathrm{L}}$ & $w_{p}$ & $\mathrm{I}_{\mathrm{p}}$ & $\mathrm{I}_{\mathrm{c}}$ \\
\hline $\begin{array}{l}\text { GeoB13935_3.28-3.33 } \\
\text { mbsf_(1) }\end{array}$ & $\begin{array}{l}\text { CLAY silty, middle } \\
\text { plastic }\end{array}$ & UM & 39.08 & 33.34 & 0.43 & 0.19 & 0.24 & 0.16 \\
\hline $\begin{array}{l}\text { GeoB13935_3.33-3.38 } \\
\text { mbsf_(2) }\end{array}$ & $\begin{array}{l}\text { CLAY silty, slightly } \\
\text { plastic }\end{array}$ & UL & 30.85 & 25.80 & 0.34 & 0.16 & 0.18 & 0.18 \\
\hline $\begin{array}{l}\text { GeoB13935_3.50-3.55 } \\
\text { mbsf_(3) }\end{array}$ & $\begin{array}{l}\text { CLAY silty, slightly } \\
\text { plastic }\end{array}$ & UL & 31.44 & 27.78 & 0.33 & 0.16 & 0.18 & 0.11 \\
\hline
\end{tabular}

\section{MECHANICAL PROPERTIES}

\begin{tabular}{|l|c|c|c|}
\hline \multicolumn{1}{|c|}{ SAMPLE } & NORMAL STRESS o' & $\begin{array}{c}\text { PEAK SHEAR } \\
\text { STRENGTH } \\
(\mathrm{kPa})\end{array}$ & $\begin{array}{c}\text { RES SHEAR } \\
\text { STRENGTH } \\
(\mathrm{kPa})\end{array}$ \\
\hline $\begin{array}{l}\text { GeoB13935_3.28-3.33 } \\
\text { mbsf_(1) }\end{array}$ & 50 & 30.45 & 30.22 \\
\hline $\begin{array}{l}\text { GeoB13935_3.33-3.38 } \\
\text { mbsf_(2) }\end{array}$ & 150 & 72.20 & 71.24 \\
\hline $\begin{array}{l}\text { GeoB13935_3.50-3.55 } \\
\text { mbsf_(3) }\end{array}$ & 250 & 124.14 & 1.008 \\
\hline
\end{tabular}

\begin{tabular}{|c|c|c|}
\hline $\begin{array}{c}\text { MOHR-COULOMB- } \\
\text { PARAMETERS }\end{array}$ & $\begin{array}{c}\text { REES SHEAR } \\
\text { STRENGTH }\end{array}$ & $\begin{array}{c}\text { RES SHEAR } \\
\text { STRENGTH }\end{array}$ \\
\hline$\mu$ & 0.4537 & 0.4284 \\
\hline$\Phi(*)$ & 24.40 & 23.19 \\
\hline$C^{\prime}(\mathrm{kPa})$ & 8.1950 & 8.1950 \\
\hline
\end{tabular}




\section{Series 2 samples}

\section{GENERAL INFORMATION}

\begin{tabular}{|llcl|}
\hline Apparatus & GIESA mbH RS2 Rahmenschergerät & & \\
\hline Frame & Consists of two stacked rings & & \\
& sample height & 25.00 & $\mathrm{~mm}$ \\
& circular surface area & 40.00 & $\mathrm{~cm}^{2}$ \\
\hline Sample & Facies I & undisturbed & \\
\hline Shear velocity v: & GeoB13936_2.25-2.32 mbsf_(1) & 0.04 & $\mathrm{~mm} / \mathrm{min}$ \\
& GeoB13936_2.32-2.39 mbsf_(2) & 0.04 & $\mathrm{~mm} / \mathrm{min}$ \\
& GeoB13936_2.39-2.46 mbsf_(3) & 0.04 & $\mathrm{~mm} / \mathrm{min}$ \\
\hline
\end{tabular}

$\mathrm{w}_{\mathrm{i}}$ - Initial water content (before test)

$\mathrm{w}_{\mathrm{f}}$ - Finale water content (after test) $\mathrm{w}_{\mathrm{L}}$ - Liquid limit

$\mathrm{w}_{\mathrm{p}}$ - plastic limit

$\mathrm{I}_{\mathrm{p}}$ - plasticity index

$\mathrm{I}_{\mathrm{c}}$ - consistency index

$\mu$ - coefficient of internal friction

$\varphi$ - angle of internal friction

c' - cohesion

\section{INDEX PROPERTIES}

\begin{tabular}{|c|c|c|c|c|} 
& \multicolumn{5}{|l|}{ ATTERBERG LIMITS } \\
\hline following DIN 18122 \\
\hline \%) & $\mathrm{W}_{\mathrm{L}}$ & $\mathrm{w}_{\mathrm{p}}$ & $\mathrm{I}_{\mathrm{p}}$ & $\mathrm{I}_{\mathrm{c}}$ \\
\hline .47 & 0.34 & 0.16 & 0.18 & - \\
& 3 & 1 & 2 & 0.199 \\
\hline 7.34 & 0.33 & 0.16 & 0.16 & - \\
& 2 & 7 & 5 & 0.225 \\
\hline .57 & 0.33 & 0.16 & 0.17 & - \\
& 1 & 0 & 1 & 0.239 \\
\hline
\end{tabular}

\section{MECHANICAL PROPERTIES}

\begin{tabular}{|l|c|c|c|}
\hline \multicolumn{1}{|c|}{ SAMPLE } & NORMAL STRESS o' & $\begin{array}{c}\text { PEAK SHEAR } \\
\text { STRENGTH } \\
(\mathrm{kPa})\end{array}$ & $\begin{array}{c}\text { RES SHEAR } \\
\text { STRENGTH } \\
(\mathrm{kPa})\end{array}$ \\
\hline $\begin{array}{l}\text { GeoB13936_2.25-2.32 } \\
\text { mbsf_(1) }\end{array}$ & 50 & 27.56 & 26.27 \\
\hline $\begin{array}{l}\text { GeoB13936_2.32-2.39 } \\
\text { mbsf_(2) }\end{array}$ & 150 & 78.74 & 73.79 \\
\hline $\begin{array}{l}\text { GeoB13936_2.39-2.46 } \\
\text { mbsf_(3) }\end{array}$ & 250 & 118.26 & 1.049 \\
\hline
\end{tabular}

\begin{tabular}{|c|c|c|}
\hline $\begin{array}{c}\text { MOHR-COULOMB- } \\
\text { PARAMETERS }\end{array}$ & $\begin{array}{c}\text { REES SHEAR } \\
\text { STRENGTH }\end{array}$ & $\begin{array}{c}\text { RES SHEAR } \\
\text { STRENGTH }\end{array}$ \\
\hline$\mu$ & 0.4486 & 0.4119 \\
\hline$\Phi\left(^{*}\right)$ & 24.16 & 22.39 \\
\hline $\mathrm{C}^{\prime}(\mathrm{kPa})$ & 7.79 & 7.79 \\
\hline
\end{tabular}

\section{Series 3 samples}

\section{GENERAL INFORMATION}

\begin{tabular}{|llccc}
\hline Apparatus & GIESA mbH RS2 Rahmenschergerät & & \\
\hline Frame & Consists of two stacked rings & & \\
& sample height & 28.50 & $\mathrm{~mm}$ \\
& circular surface area & 40.00 & $\mathrm{~cm}^{2}$ \\
\hline Sample & Facies I & undisturbed & \\
\hline Shear velocity v: & GeoB13935_2.81-2.90 mbsf_(1) & 0.3 & $\mathrm{~mm} / \mathrm{min}$ \\
& GeoB13935_2.81-2.90 mbsf_(2) & 0.3 & $\mathrm{~mm} / \mathrm{min}$ \\
& GeoB13935_2.81-2.90 mbsf_(3) & 0.3 & $\mathrm{~mm} / \mathrm{min}$ \\
\hline
\end{tabular}

$\mathrm{w}_{\mathrm{i}}$ - Initial water content (before test)

$\mathrm{w}_{\mathrm{f}}$ - Finale water content (after test) $\mathrm{w}_{\mathrm{L}}$ - Liquid limit

$\mathrm{w}_{\mathrm{p}}$ - plastic limit

$\mathrm{I}_{\mathrm{p}}$ - plasticity index

$\mathrm{I}_{\mathrm{c}}$ - consistency index

$\mu$ - coefficient of internal friction

$\varphi$ - angle of internal friction

c' - cohesion 


\section{INDEX PROPERTIES}

\begin{tabular}{|c|c|c|c|c|c|c|c|c|}
\hline \multirow[t]{2}{*}{ SAMPLE } & \multirow[t]{2}{*}{$\begin{array}{l}\text { SOIL TYPE } \\
\text { following DIN 4022-1 }\end{array}$} & \multirow[t]{2}{*}{$\begin{array}{l}\text { SOIL GROUP } \\
\text { following DIN } 18196\end{array}$} & \multicolumn{2}{|c|}{$\begin{array}{l}\text { WATER } \\
\text { CONTENT } \\
\text { following DIN 18121- } \\
1\end{array}$} & \multicolumn{4}{|c|}{$\begin{array}{l}\text { ATTERBERG LIMITS } \\
\text { following DIN } 18122\end{array}$} \\
\hline & & & $w_{i}(\%)$ & $w_{f}(\%)$ & $\mathrm{W}_{\mathrm{L}}$ & $\mathrm{W}_{\mathrm{p}}$ & $I_{p}$ & $\mathrm{I}_{\mathrm{c}}$ \\
\hline $\begin{array}{l}\text { GeoB13935_2.81-2.90 } \\
\text { mbsf_(1) }\end{array}$ & SILT, sandy & SU & & 36.20 & -- & -- & -- & -- \\
\hline $\begin{array}{l}\text { GeoB13935_2.81-2.90 } \\
\text { mbsf_(2) }\end{array}$ & SILT, sandy & SU & & $\begin{array}{l}31.51 . \\
30.76\end{array}$ & -- & -- & -- & -- \\
\hline $\begin{array}{l}\text { GeoB13935_2.81-2.90 } \\
\text { mbsf_(3) }\end{array}$ & SILT, sandy & SU & & & - & - & - & - \\
\hline
\end{tabular}

\section{MECHANICAL PROPERTIES}

\begin{tabular}{|l|c|c|c|}
\hline \multicolumn{1}{|c|}{ SAMPLE } & NORMAL STRESS o' & $\begin{array}{c}\text { PEAK SHEAR } \\
\text { STRENGTH } \\
(\mathrm{kPa})\end{array}$ & $\begin{array}{c}\text { RES SHEAR } \\
\text { STRENGTH } \\
(\mathrm{kPa})\end{array}$ \\
\hline $\begin{array}{l}\text { GeoB13935_2.81-2.90 } \\
\text { mbsf_(1) }\end{array}$ & 50 & 26.40 & 25.41 \\
\hline $\begin{array}{l}\text { GeoB13935_2.81-2.90 } \\
\text { mbsf_(2) }\end{array}$ & 150 & 79.57 & 73.15 \\
\hline $\begin{array}{l}\text { GeoB13935_2.81-2.90 } \\
\text { mbsf_(3) }\end{array}$ & 250 & 127.99 & 1.039 \\
\hline
\end{tabular}

\begin{tabular}{|c|c|c|}
\hline $\begin{array}{c}\text { MOHR-COULOMB- } \\
\text { PARAMETERS }\end{array}$ & $\begin{array}{c}\text { REES SHEAR } \\
\text { STRENGTH }\end{array}$ & $\begin{array}{c}\text { RES SHEAR } \\
\text { STRENGTH }\end{array}$ \\
\hline$\mu$ & 0.5079 & 0.4775 \\
\hline$\Phi\left(^{*}\right)$ & 26.93 & 25.52 \\
\hline$C^{\prime}(\mathrm{kPa})$ & 1.80 & 1.53 \\
\hline
\end{tabular}


Table 4

DYNAMIC TRIAXIAL EXPERIMENTS

\section{Cyclic testing}

Properties at failure: $\Delta u=0.9 \&$ DA axial strain $=4 \%$

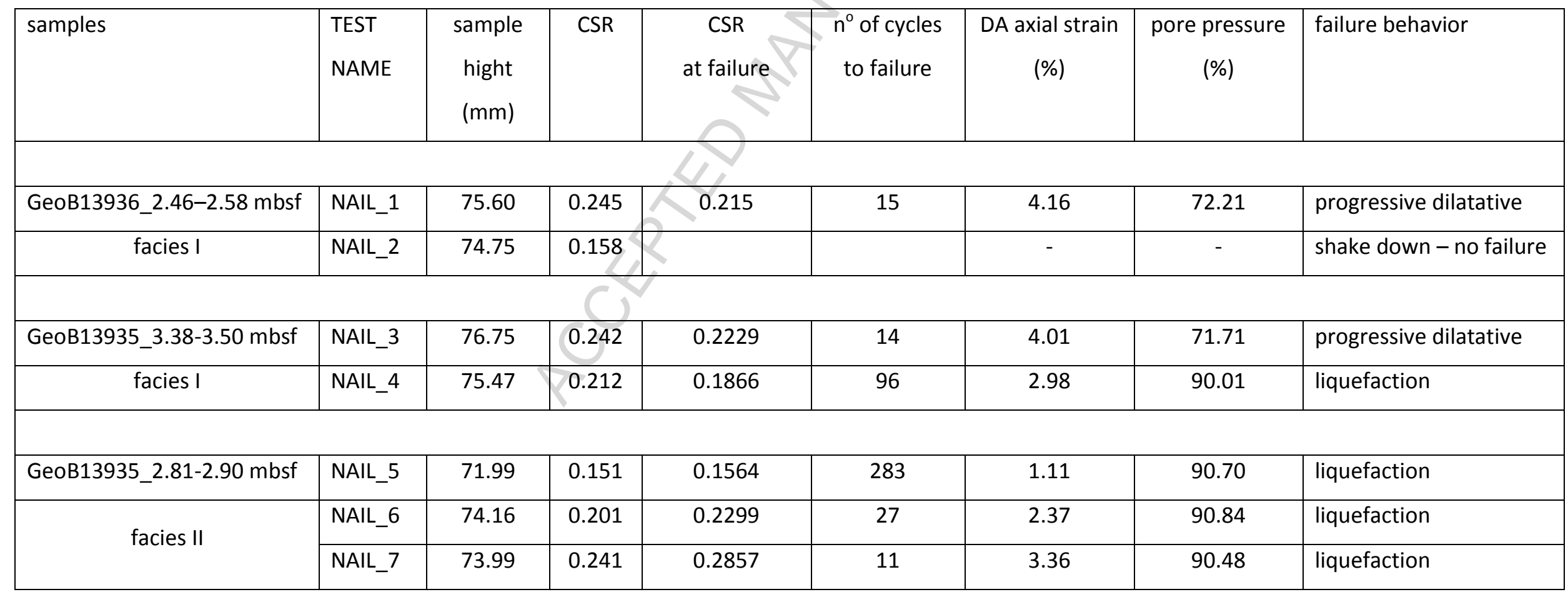


Table 5

\section{PERMEABILITY}

Gravity cores GeoB

13957_3-1,6

13957_3-2,1

13957_4-2,8

13957_5-4,4

13958_6-5,2

$13956 \quad 2-1,3$

$13956 \_2-1,8$

13956_3-2,8

13956_5-4,4 confining stress

$30 \mathrm{kPa}$

$45 \mathrm{kPa}$

$60 \mathrm{kPa}$

$80 \mathrm{kPa}$

$100 \mathrm{kPa}$

$25 \mathrm{kPa}$

$45 \mathrm{kPa}$

$60 \mathrm{kPa}$

$100 \mathrm{kPa}$ kf (m/s)

2,72E-09

1,35E-09

2,27E-09

1,99E-09

1,95E-09

2,59E-09

1,95E-09

1,90E-09

1,51E-09

\section{Puddingstones}

unaltered \#1

$6,7185 \mathrm{E}-12$

unaltered \#2

2,2846E-11

unaltered \#3

2,0782E-11

unaltered \#4

2,48E-11

altered \#1

7,4317E-10

altered \#2

1,5897E-09

altered \#3

1,2773E-10

altered \#4

2,5335E-10

altered \# 5

6,4577E-09

altered \#6

2,2389E-10

altered \#7

6,2775E-09 